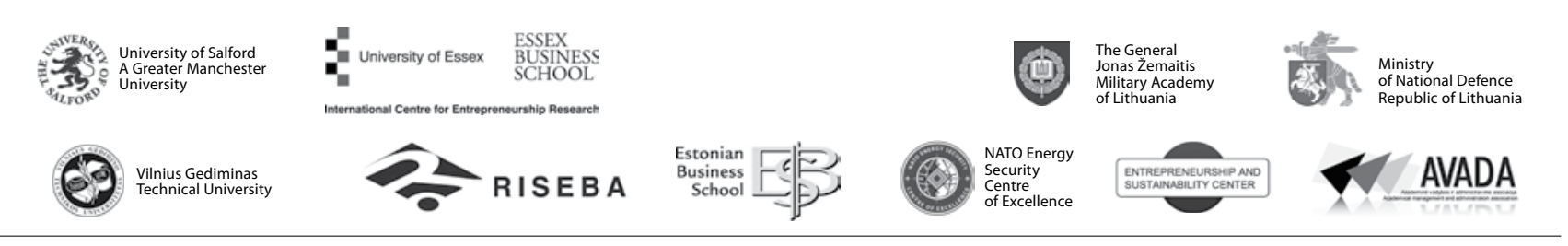

\author{
JOURNAL OF SECURITY AND SUSTAINABILITY ISSUES \\ ISSN 2029-7017 print/ISSN 2029-7025 online \\ 2016 September Volume 6 Number 1 \\ http://dx.doi.org/10.9770/jssi.2016.6.1(1)
}

\title{
SECURITY PRECONDITIONS: UNDERSTANDING MIGRATORY ROUTES
}

\author{
Col. János Besenyő PhD \\ Scientific Research Centre of the General Staff of the Hungarian Defence Forces, \\ E-mail:besenyo.janos@hm.gov.hu
}

Received 10 January 2016; accepted 20 May 2016

\begin{abstract}
This paper is mapping the migratory routes to Europe, details their characteristics and briefs the ongoing changes in the political, economic and social sphere. Though many people think that migration towards Europe is a recent phenomenon, it have been lasting - with diverse intensity - for centuries now, even its main tracks remained almost the same. There are routes that are crowded with migrants at one year and - due to European border authorities' counter-measurements - are empty a few months later. Considering the adaptability of these migratory routes, detecting, tracking and detailing them are a significant challenge, although, in order to manage the recent crisis, analysis and the appropriate use of the information on migratory routes are essential. This motivated me to briefly delineate the main paths used by the illegal migrants on their ways to Europe. This paper however, does not elaborate on the movements within the EU and the ways connecting the member countries.
\end{abstract}

Keywords: illegal migration, border defence, Europe, Balkan, Mediterranean, Africa, migrant

Reference to this paper should be made as follows: Besenyő, J. 2016. Security preconditions: understanding migratory routes, Journal of Security and Sustainability Issues 6 (1): 5-26. DOI: http://dx.doi.org/10.9770/jssi.2016.6.1(1)

JEL classification: J61, K4

\section{Introduction}

Defending the $11,000 \mathrm{~km}$ land and 43,000 km maritime border from the immigrants (Düvel \& Vollmer 2011) is an emerging problem for the 28 member countries of the EU, meanwhile, since 1990's it is also needed to handle the problematics of the increasing legal and illegal migration. Migrants heading to Europe use different, periodically changing routes to reach their destination. The use of these paths and their continuous adaptation to the changes in the environment are influenced by many factors such as the territory's socio-economic status (e.g. Njaramba et. al. 2015; Rezk et al. 2015; Rezk et al. 2016; Śimelytė et al. 2016), the activity of the authorities in charge, the work of smuggling groups, the visa and migration policy of the concerned countries, active conflicts or weather conditions. These factors can easily modify a route or migrants may also choose a new path to the host countries. We have seen examples for both in the recent years. One certain point is that all those who want to get into „Fortress Europe”, sooner or later will find a path leading to the continent. In the followings I present these main routes for my readers

\section{Western and Central African route}

These parallel route-systems, which are containing some frequently and less frequently used paths, are used by immigrants from the Western African countries (Mali, Ivory Coast, Ghana, Togo, Benin, Burkina Faso, Senegal, Gambia etc.) and the Central African states (Niger, Nigeria, Cameroon, Chad etc.) (Global Initiative 
against Transnational Organized Crime 2014). The route is heading from Western Africa through Central Africa towards Libya. Since centuries, this way was used not only by merchants but by smaller or bigger ethnic groups who had to set sail because of changing circumstances (UNODC Regional Office for West and Central Africa 2012). When colonizing powers created the current African states, migratory movements have decreased significantly, but they could never be stopped (De Haas 2007). In the last decades, these movements have amplified, but mainly towards two directions, Northern African states and the European countries. Traditionally, the trade in different goods - gold, copper, salt, slaves, ivory, European manufactured products etc. - as well as inner and Europe-targeting migratory movements took place on the caravan-routes (Bob-Milliar, GM \& Bob-Milliar, GK 2013). The colonizing powers used ports for trade more likely, so the significance of the caravan-routes decreased. Later they were used by only smugglers, immigrants and those who wanted to seek a new job in the Northern African states, for example in Libya or Algeria. Previously, these routes did not have any possessor, nowadays armed groups compete for paths, being able to engage in clashes for controlling them (International Crisis Group 2015).

The first meeting point of Western African migrants (Frontex 2016a; UNODC Regional Office for West and Central Africa 2012) ${ }^{1}$ is the town of Ouagadougou in Burkina Faso, where they can reach through Gao (Mali), Agadez (Niger), Dirkou (Niger), Madama (Niger), Tumo (Niger) to Al Wigh in Libya. From here through Gathrun, Murzuk, Um Al-Aranib, Sabha, Gharyan, and Tarhouna, they get to Tripoli and other Libyan ports (Altai Consulting \& UNHCR 2013; MIGREUROP 2010).

From Gao there is an another way to arrive to Libya, crossing Kidal (Mali), Tessalit (Mali), Borj Mokhtar (Algéria) and Agadez (Mali), Arlit (Mali), Assamaka (Mali), Tinzaouaten (Algeria), Guezzam (Algeria) and Tamanrasset (Algeria) (Altai Consulting \& UNHCR 2013; Düvel \& Vollmer 2011; Global Initiative against Transnational Organized Crime 2014). ${ }^{2}$ At the bigger meeting and starting points - like Tinzaouaten, Tamanrasset and Agadez - a whole industry have been built upon the migrants heading to North. Some of them also acquires a job to earn the money needed to continue the journey or to work for their fares (Bob-Milliar, GM \& Bob-Milliar, GK 2013; MIGREUROP 2010). This means that a part of the migrants settle for months or years before moving on to Europe. Tamanrasset (Algeria) used to have almost 3,000 inhabitants in 1966, with ten percent of sub-Saharan origins. In 1990, fifty percent of the 65,000 residents were sub-Saharan (ECOWAS 2006). Other towns like Agadez (Frontex 2016a), ${ }^{3}$ Gao, Nouadhibou or Oujda (Schapendonk 2012) experienced the same rapid evolution. Legitimately practicing "tourist offices" in these cities transport migrants through the Sahara with coaches of twenty-five or thirty passengers in convoys of 160-200 person (Frontex 2016a; Monzini 2003). We also have to mention, that this route is getting more and more dangerous because it is crossing the desert (Brian \& Laczko 2014; De Bruycker, Di Bartolomeo \& Fargues 2013) 4,5 and the activity of AQIM and other Islamic terror organizations (Mujao, Ansar Dine etc.) are deeply effecting migration movements (Frontex 2016a). Radicals often ambush and rob migrants or abduct them for ransom. We have information about another, less frequently used path through Chad to Lybia (Ndjamena - Moussoro - Faya - Zouar - Bardaï Ghatrun - Sabha), which is used mostly by refugees from Cameroon, Sudan and Chad.

\footnotetext{
1 I use this term for ECOWAS citizens, who - on the basis of the agreements - can travel easily and relatively cheap and are assured to stay for 90 days in any of the member countries without any visa.

2 This route is mostly used by Mali citizens, who can travel visa-free in Algeria, so they travel under minimal control to the neighboring states. This made the Malian personal documents very popular on the black market. Counterfeiting is a new industry for smugglers. Every year 8-10,000 migrants are caught with fake documents, but much more can enter through the EU's borders. There is also a huge demand for Libyan documents, which are sold in bulk with refugee and NGO IDs by smugglers.

3 This city is famous, since gold was found in 2013, $700 \mathrm{kms}$ away, in Djado. Since then, almost every migrant tried to mine gold, but only few managed to earn enough money to travel further to Europe. Though 100,000 African migrants crossed the city in 2015, excluding the 10,000 individuals who settled there temporarily or permanently.

4 Although crossing the desert is not easy even with an experienced guide, many depart individually. A lot of them never arrive, their bodies are often found by the following groups. This happened on 31st October, 2013 on the route between Niger and Algeria, where 92 illegal migrants' (mostly women and children) corpse were found. They got lost during the way through the Sahara.

5 According to a study, between 1996 and 2013 at least 1790 migrants died by crossing the Sahara.
} 
Earlier, illegal migrants used to hide amongst the travellers with visa, using the official air corridors and waterways, but after European states introduced stricter border control system, migrants are trying to enter Europe through the Mediterranean Sea on boats with the help of smuggling groups that active through the western Mediterranean route (De Haas 2007). The significance of the path is growing in conjunction with the number of migrants using them. Between March and August 2013, five thousand western Africans per month have left the city of Agadez to North Africa, while in 2013 half of the registered illegal immigrants in Lampedusa arrived from here (Global Initiative against Transnational Organized Crime 2014). Different estimates claim that approximately 60-80,000 migrants arrived yearly through the Mediterranean, but only two third of them tried to get into Europe. Others state that even 120,000 sub-Saharan immigrants may arrive to North Africa through this way (De Haas 2007). Many may think that it is a huge number, though there are almost 800,000 westAfrican immigrants in the cities of the European continent, and the amount of the north-African immigrants is over 2,600,000 (De Haas 2007). Those who use the help of smugglers, pay an average amount of 2-3,000 USD between Agadez and the Libyan coast. Smugglers make a great profit from the increasing amount of migrants, their annual income may reach up to 150 Million USD (Global Initiative against Transnational Organized Crime 2014; UNODC Regional Office for West and Central Africa 2012).

\section{Western Mediterranean route}

This route (Frontex 2015a) is actually the continuation of the western and central African route, used by Algerians, Moroccans and sub-Saharans trying to get into Spain, France or Italy from Northern Africa through the sea. Migrants try to board for Spain mainly in the ports of Almeria and Algeciras. Many try to get to the two northern African enclave of Spain, Ceuta and Mellila (Brian \& Laczko 2014).

There are two ways to reach the western Mediterranean region from the western African states. First, via the coast of the Atlantic Ocean, or from the East through the Sahara. The coastal route is favourable for migrants from Senegal, Mauritania, Tunisia, Guinea, Mali, Cameroon, Nigeria, Ivory Coast and Benin, but in the recent years people have arrived to the region from Eritrea, Somalia, Syria, and even from Afghanistan (Altai Consulting \& IOM MENA Regional Office 2015). The changes of the amount of migrants via this route are shown in Figure 1.

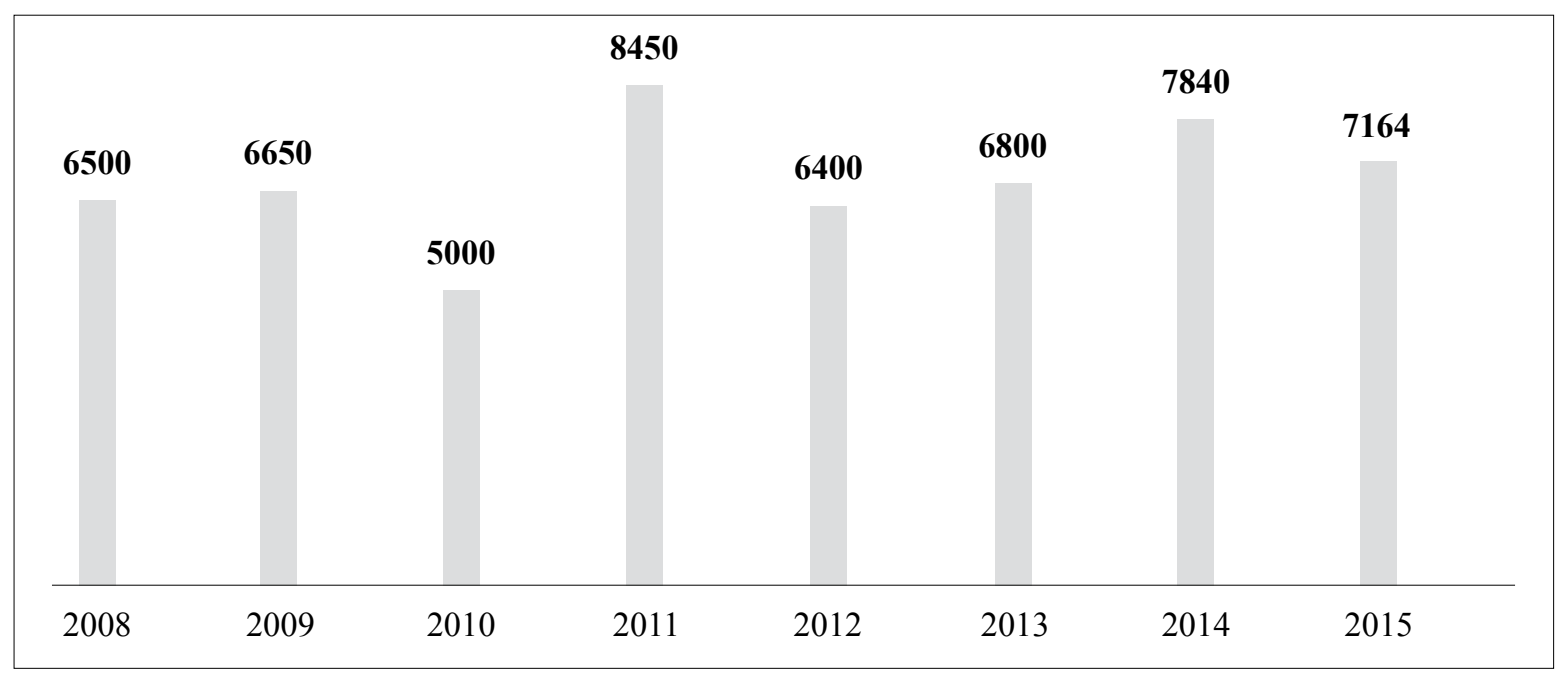

Fig. 1. Migrants arriving through Western Mediterranean route 2008-2015

Sources: Frontex 2016a; European Commission DG Migration and Home Affairs 2015

Illegal migrants are trying to reach the Canary Islands from the coast of the African continent with smaller ships and boats, while from Morocco, the migrants arrive to the Spanish territory with the help of individual smugglers or smaller smuggling groups. Smugglers and migrants use the outlying small ports of the western Saharan coast also very often in order to reach the Canary Island quickly. As Western Sahara is very close to the southern 
borders of the EU (Canary Islands are located within 100 kilometres to the coast), it became one of the junction points of international migration towards to the European countries. For years, migrants arrived through the old caravan routes. The most important focal points were Accra (Ghana), Bamako (Mali), Gao (Mali), Arlit (Niger) and Niamey (Niger), from where groups first reach the city of Tamanrasset in southern Algeria, then via Oran (Algeria), Maghina (Algeria) and Oujda (Morocco) they departed to Western Sahara, Mauritania and Tunisia (Altai Consulting \& IOM MENA Regional Office 2015). ${ }^{6}$

Migratory wave crossing Western Sahara started in the middle of the 1990's, when migrants, heading to Gibraltar, started to use dinghies increasingly to travel to Europe from the Atlantic ports (De Haas 2007; Fargues \& Bonfanti 2014). ${ }^{7}$ As there is no central government in Polisario controlled territories, and the Mauritanian border guards' presence is only symbolic, more and more refugees turn to Western Sahara and Mauritania instead of Morocco on their way to Europe (MIGREUROP 2010). This is why the Moroccan government accused the leaders of SADR and Algeria many times for supporting the refugees arriving into Morocco even by destabilizing the country. The concerned parties disavowed these accusations, but have not stopped the flow of illegal migrants. Peacekeepers of MINURSO frequently reported that during a patrol in the desert, they are able to recognize more and more (sometimes a whole caravan of) Black African refugees among the smugglers and Polisario soldiers. The UN have warned the leaders of Polisario to restrain the flood of illegal migrants.

Near Tifariti Sahrawians have arrested a group of Pakistani and Bangladeshi refugees in 2004, who have been imprisoned first, then released at the Mauritanian border (Besenyö 2011). But this single act did not stop the migratory wave. In the years of 2005 and 2006 an increasing number of migrants arrived from Senegal, Gambia, Sierra Leone, Liberia, Mali, Ivory Coast, Ghana, Nigeria, the democratic Republic of Congo, Cameroon, Sudan, and even from the far eastern Asian countries. Instead of the 2005's 4472 refugees, only between January and September 2006, 24,000 migrants arrived without any legal permission to the Canary Islands. Migrants, who have been deported by Maghreb countries' offices, usually do not return to their homeland, but settle down on site and try to get into Europe later (Altai Consulting \& IOM MENA Regional Office 2015).

Some human rights organizations (UNHCR, Amnesty International and Human Rights Watch) claim that refugees are mishandled by northern African and European border guard members and policemen, violating basic human norms. It cannot be mitigated by the fact that Europe is fed up with the increasingly radicalized Muslim crowds, who should be able to provoke bloody riots in a second from a routine police control, and who are professedly hostile to the recipient states. Because of the last months' terror attacks and the amount of migrants settled in Europe, Europeans tend to approach illegal migration, which - compared to the growing amount of disadvantages - have minimal benefits from the viewpoint of security.

There is another route joining into the coastal path, starting from Dakar (Senegal) via Nouadhibou (Mauritania) (Altai Consulting \& IOM MENA Regional Office 2015), ${ }^{8}$ Bir-Gandouz (Western Sahara, Morocco), Dakhla (Western Sahara, Morocco), Laayoune (Western Sahara, Morocco), Casablanca (Morocco), Rabat (Morocco), Oujda (Morocco) and Nador (Morocco). This way is mostly used by migrants from Senegal, Nigeria, Ivory Coast and Guinea. The number of migrants on this path was the highest in 2006, when almost 32,000 person arrived illegally to the Canary Islands (Schapendonk 2012). In the next year, this number decreased almost by 60 per cent, due to the Spanish agreement with Morocco, Senegal and Mauritania, according to what these states stop migrants before they reach the Atlantic coast (Frontex 2010a; Urban 2015). Spain provided significant economic support for the affected states. Repatriation agreements have been signed between Spain and source countries in order to

\footnotetext{
6 Moroccan government started to build a fence system on the popular migratory route at the Algerian-Moroccan border recently. It is not ready yet, but the number of arriving migrants is in constant decrease. Migrants are forced to find an alternative way after the fence is ready.

7 Morocco and Spain are divided by a $13 \mathrm{~km}$ long strait here, which made it a popular target of African migrants, trying to get into Europe. Though it is not too wide, the crossing was made difficult by vortex and heavy freight traffic. Many migrants died here in the 1990's, so Spanish and Moroccan authorities increased the number and efficiency of patrols, this is why migrants have to use longer routes, like the one heading to Canary Islands.

8 Cooperating with Mauritanians, Spanish border guards run an office here, as the city is not only a main meeting point for migrants, but a huge market for different fake documents.
} 
send illegal migrants back to their homeland. The Spanish border guarding system was reinforced by setting up the Sistema Integral de Vigilancia Exterior (SIVE) marine control system (Urban 2015). Spain also joined the Frontex's initiative, the „Joint Operation Hera”. This was the first joint marine operation of the European countries (France, Germany, Netherlands, Italy, Norway, Finland, Portugal and the United Kingdom), starting on 17th July, 2006 in cooperation with two non-EU member states, Senegal and Mauritania. Though the mission's mandate lasted until October 2006, it was extended several times. ${ }^{9}$ The mission headquarters operated in the Canary Islands, the ships, planes and helicopters were deployed to four zones of the African shores (Zone 1: Western Sahara, Zone 2: Mauritania, Zone 3: Senegal, Zone 4: Cape Verde) in order to prevent illegal entering to the Canary Islands. Several months before starting the operation, due to the „Cayuco Crisis” (MIGREUROP 2010), ${ }^{10}$ a record number of illegal migrants (32,000 individuals) arrived to the Islands, and Spanish authorities were not prepared for them. The primary target for operatives was to return migrants' ships to the western African shores and to save migrants from the Atlantic Ocean. Alongside they participated in the identification and interrogation of the arriving migrants, thereby they could trace smuggling networks in the area. These pieces of information were essential to fight effectively against illegal migration. The operation was such a success that the number of illegal migrants have decreased in 2007 to 12,500, then in 2008 to 9,200 and in 2009 to 2,200 individuals. According to Frontex, Operation Hera was one of the most successful operations of the agency (MIGREUROP 2010) and upon its experiences they started subsequent marine operations (MINERVA, INDALO, POSEIDON, ZEUS, NAUTILUS and HERMES) in order to fight off illegal migration (Borelli \& Stanford 2014; Brian \& Laczko 2014; De Haas 2007; Frontex 2010b). Additionally, in 2006 the Spanish Border Guards launched "Operation Seahorse Atlantic" having its HQ in the Canary Islands. Cooperating with Portugal, Morocco, Senegal, Mauritania, Cape Verde, Gambia and Bissau Guinea, they tried to prevent the docking of migrants' ships (MIGREUROP 2010).

As Figure 2 indicates, results show that the number of migrants arriving to Canary Islands decreased permanently between 2008 and 2012. In the last year border guards arrested altogether 173 illegal immigrants from Morocco. We have similar statistics for 2013 and 2014, but recently their number started to increase (Frontex 2015b) and compared to the 2014 data, almost three times more illegal immigrants arrived in 2015 . Though it makes Spanish authorities cautious, several researchers in this field claim that this path has lost its former significance and migrants rather prefer the western or central African route (Altai Consulting \& IOM MENA Regional Office 2015; Frontex 2016a).

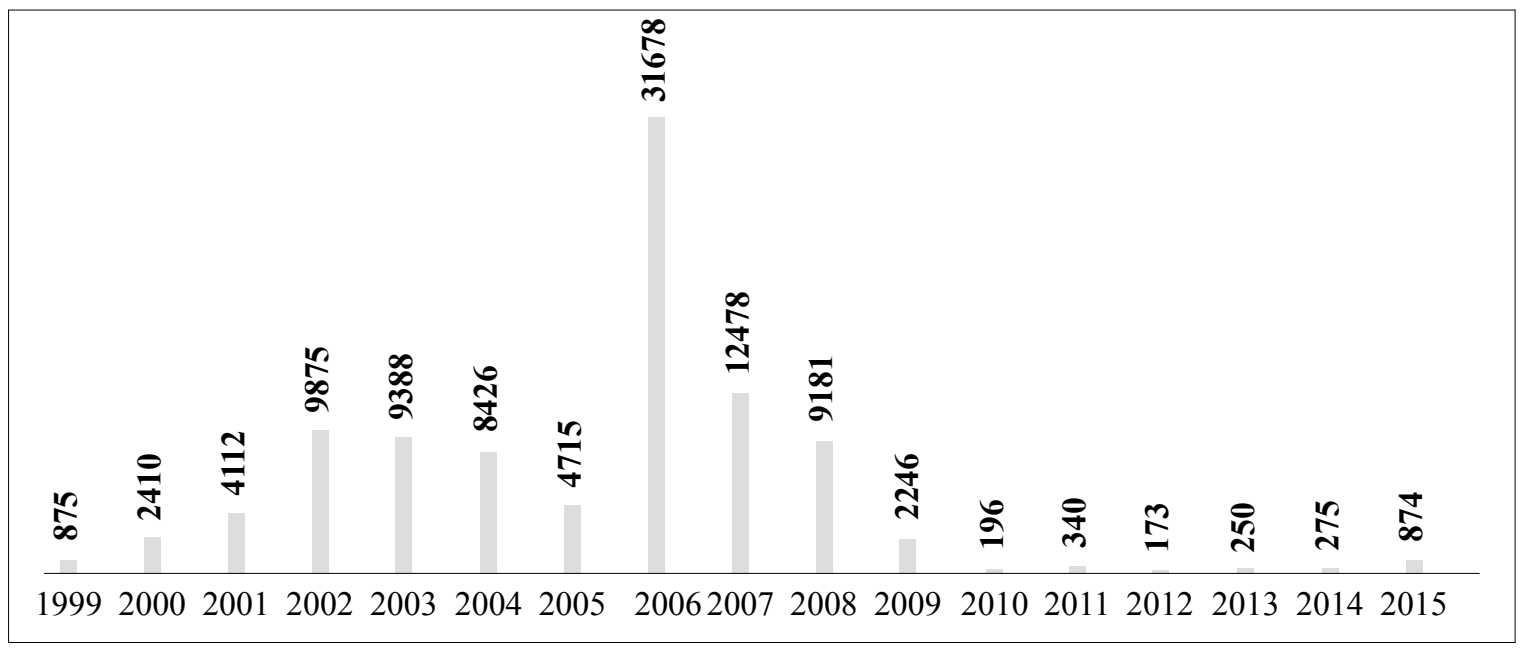

Fig. 2. Migrants arriving by ship to Canary Islands 1999-2015

Sources: Altai Consulting \& IOM MENA Regional Office 2015; UNODC 2013;

De Bruycker, Di Bartolomeo \& Fargues 2013; Frontex 2016b

9 Hera II from August 2006 to December, and Hera III from February 2007 to April. Later the mandate of the operation was extended from year to year.

${ }^{10}$ Cayucos are small fishing ships in Senegal and Mauritania that are bought or rented by migrants heading to Canary Islands. These ships are good for coastal activities, not for longer maritime routes. Thereby many migrants who left by these ships, never arrived to the Islands. 
Not everyone can afford the high and increasing fees of the marine routes (de Haas 2007), ${ }^{11}$ so more and more people try to get into Ceuta and Melilla through land-routes (Altai Consulting \& IOM MENA Regional Office 2015; Frontex 2016a). ${ }^{12}$ Although they are located in the African continent, these two cities are integral parts of Spain, so when the country joined the EU in 1986, these cities have also become parts of Europe. These cities are significant for more reasons, such as they connect Africa and Europe, the developed western countries with the Third World, Christianity and Islam. Drug smuggling route from Morocco to Spain pass through the cities, too (Castan Pinos 2009). Of course, smugglers have widened their portfolio with the beneficiary human smuggling and organize the trip of migrants to these two enclaves. These young men, mostly in a good condition, regularly hide from Moroccan authorities in the nearby woods. Later, when they are sufficient enough to try to breach, they almost besiege the $6 \mathrm{~m}$ high fences with barbed wire around the towns (Castan Pinos 2009; MIGREUROP 2010; Urban 2015). ${ }^{13}$ Though most of them are pushed back, some gets into European territory and immediately apply for refugee status. In 2005, so many migrants tried to climb over the fences around the enclaves, that Spain upgraded these fences like fortresses. The country strengthened its police and border guard units, increased the numbers of patrols, so the number of illegal migrants getting to European territory have significantly decreased (MIGREUROP 2010). This method, however did not stop the migrants, who now are forced to find new strategies (MIGREUROP 2010) ${ }^{14}$ or explore new routes (Reitano 2015). Obviously, Spanish authorities are trying to react as soon as possible, so there is a „competition” between migrants and border guards.

Figure 3 shows that today Spain is less luring to migrants. Due to the world economic crisis, the number of unemployed in Spain increased, which made even residents only able to apply for the less desirable jobs. Through this change, jobs that were earlier reserved for immigrants, are filled with locals. Despite this, from 2011 the amount of illegal border crossings from Algeria and the sub-Sahrawian states increased. In 2014, the number of migrants have reached the top, as a result of the simultaneous crises in the African continent (Mali, South Sudan, Nigeria, Chad, and Central African Republic etc.). Due to this, an enormous number of African inhabitants were forced to leave their home, and tried to reach Europe. Despite this, relatively few immigrants arrived via this route (Frontex 2015b; Reitano \& Tinti 2015). ${ }^{15}$ Figure 3 shows the amount of registered illegal migrants in Ceuta and Melilla between 1999 and 2015.

11 This amount depends on the distance, but can be between 400 and 2,000 USD.

12 Migrants rather try to get into Melilla, since it is less guarded and fake Moroccan documents are less likely to be identified. Compensating migratory pressure, Moroccans started to build their own fence next to the Spanish defense lines in order to stop the entering migrants. Of course, it is not a perfect solution, border guards must deter migrants in other efficient ways, too. In February 2014, during a "migrant's siege" Spanish border guards shot at the migrants. 15 people died.

13 Building fences around the cities started in 1993 in Ceuta with a 8,2 km long section, then works continued with the fence in Melilla $(10,5 \mathrm{~km})$ in 1996 . The building of these fences was supported by the EU almost from the beginning (1995) and almost the $2 / 3$ of the expenses was paid by the international organization. Up to now, it became a complex fortress equipped with modern devices with a purpose to stop migratory wave towards Europe. The EU also supported the fortification of more Maghreb states' border guards through MEDA (European Neighborhood Partnership Instrument) program in order to make illegal border crossing more difficult.

14 One of these strategies hide amongst the cca. 20,000 Moroccans (portadoras, mujeres mulas) who work in these two cities or try to get on the trucks heading to the city.

15 This constitutes a 15 per cent growth compared to 2013 data... 


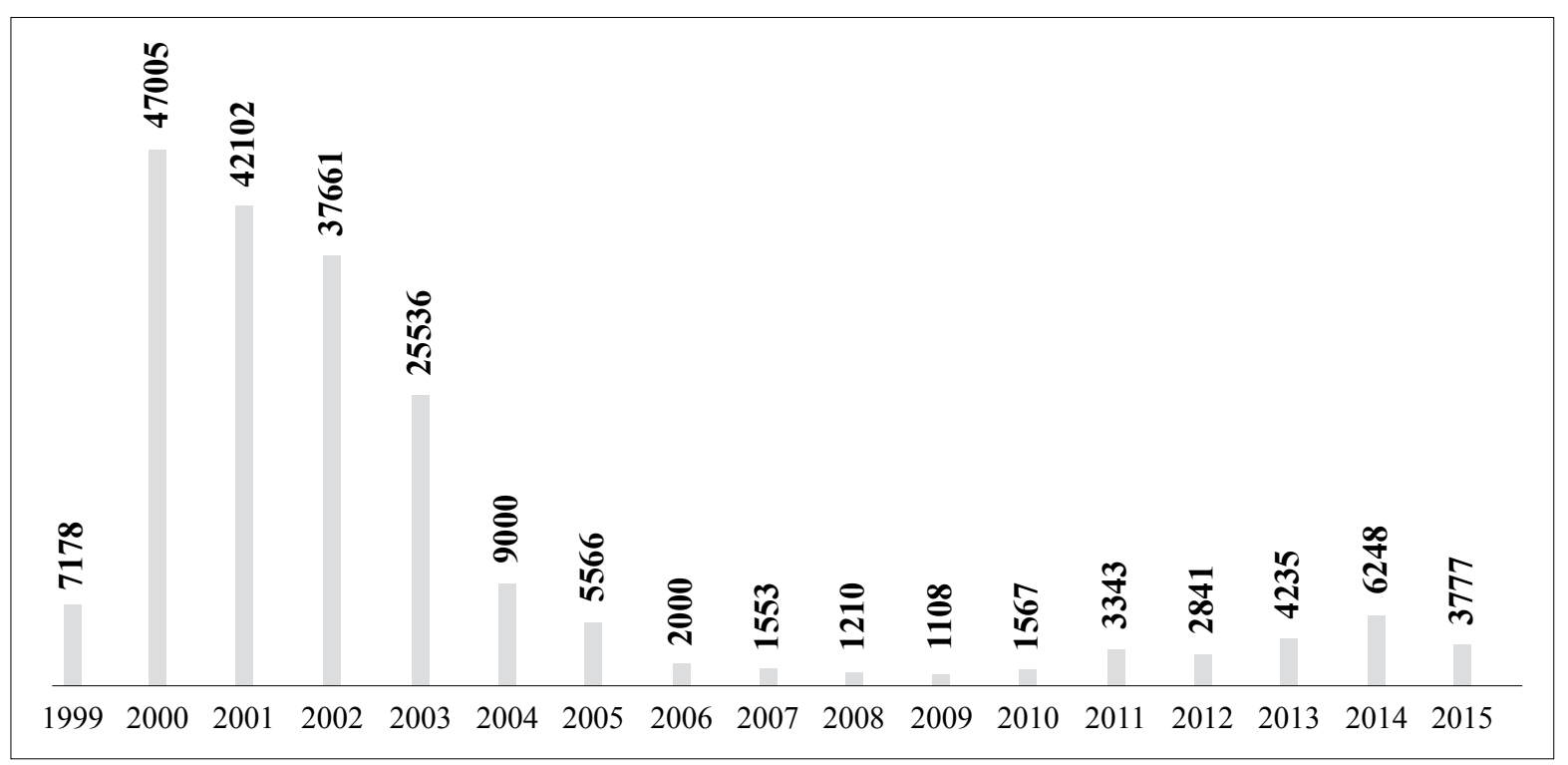

Fig. 3. Illegal immigrants, Ceuta and Mellila 1999 - 2015

Sources: Altai Consulting \& IOM MENA Regional Office 2015; UNODC 2013; Migreurop \& Gadem 2015

\section{Central Mediterranean route}

Experts believe that this route (Frontex 2015a) transports the biggest amount of immigrants to Europe - 60 per cent of the total amount (Frontex 2015b; Kuschminder, De Bresser \& Siegel 2015). This route leads from the northern African Libya through the Mediterranean Sea towards Italy and Malta. Immigrants arrive to the Libyan meeting points from the sates of the Horn of Africa (Somalia, Eritrea, etc.), the western African states and - by aeroplane - from Asia (Altai Consulting \& UNHCR 2013; Brian \& Laczko 2014). Until Kaddafi's regime was stable, Libyan economy provided solid livelihoods for many migrants, and the state - due to agreements with European countries - controlled and limited migration towards Europe (Bob-Milliar, GM \& Bob-Milliar, GK 2013; Borelli \& Stanford 2014; Global Initiative against Transnational Organized Crime 2014). ${ }^{16}$ This big state is rich in mineral resources, but has a small population and lack of skilled workers in many fields, that made it a popular destination for immigrants who were easily able to have a job. Those, who wanted to move forward to Europe, could collect money for the future trip (Bob-Milliar, GM \& Bob-Milliar, GK 2013). In the last years, more and more unskilled or weakly trained migrants have arrived to the country, whose job opportunities did not live up to the expectations, which generated a serious tension between Libyans and immigrants (Altai Consulting \& IOM MENA Regional Office 2015; De Haas 2007; Frontex 2010a; Frontex 2015b).

Though many think that all African migrants are trying to get into Europe, this is not true. Most of them do not want to leave the continent, but are trying to get along in the northern African states where living conditions are better than in their homeland. By the way, this suits to the recent regional economical migration processes (Bob-Milliar, GM \& Bob-Milliar, GK 2013; Global Initiative against Transnational Organized Crime 2014). Every year, 65,000 - 120,000 immigrants arrive to these states. 20-38 per cent of them move towards Europe, the others stay in North Africa (mostly in Libya) (De Haas 2007). Despite, it seems that many are trying to reach Europe and nobody is willing to stop them, because the Arab Spring tossed the country into chaos: separate militant groups fight each other for power in the destabilized country (Frontex 2015b; International Crisis Group 2015; UNODC Regional Office for West and Central Africa 2012). This uncontrollable situation attracts illegal migrants who are trying to get to the Egadi Islands, Pantelleria, Lampedusa, Linosa, Sicily, Malta or to the continental shores using different kinds of boats, most of which are not suitable for maritime shipping. Starting from the coasts of Al-Zuwarah, Zliten, Zawiya, Tripoli and Benghazi, smugglers tow these significantly over-

${ }^{16}$ Libyan authorities introduced limitations on migrants' movement. Many time authorities took violent actions against sub-Saharan migrants, even carrying them out to the desert, leaving them all alone. Most of these migrants died. 
whelmed and weakly equipped boats into the open sea and let them suffer their fates (Altai Consulting \& IOM MENA Regional Office 2015; Global Initiative against Transnational Organized Crime 2014; Monzini 2003). A part of them sink before reaching the shores. This makes authorities not only to guard maritime borders, but also to save migrants struggling for their lives out from the sea (Altai Consulting \& IOM MENA Regional Office 2015; Human Rights Watch 2015; van Reisen, Estefanos \& Rijken 2013; Reitano 2015). ${ }^{17}$ The high number of shipwrecks are also linked with smugglers, who do not teach migrants any navigation skills or provide any maritime experience (Global Initiative against Transnational Organized Crime 2014). In the last one and half year the role of Egypt became more significant as a meeting point and as a direct starting point for Europe (Altai Consulting \& IOM MENA Regional Office 2015). ${ }^{18}$

Despite its hazards, the Central Mediterranean route is favoured by African migrants, because of the proximity of the European shores, so the number of illegal migrants is permanently increasing (Fargues \& Bonfanti 2014; Frontex 2015b). Between 2001 and 2011, 190,425 illegal migrant were registered in Lampedusa, whose 60 per cent arrived from Libya (Altai Consulting \& UNHCR 2013). In 2008 almost 40,000 migrants arrived to Italy (mostly to the island of Lampedusa) and Malta from Nigeria, Somalia and Eritrea. This crowd almost disappeared in 2009 due to the aforementioned reasons, so the Italian border guards could take a breath (MIGREUROP 2010). This peaceful period ended in 2011, when following the Arab Spring 64,000 illegal migrants arrived to Europe via this route. Only between January and March 28,829 Tunisian refugees arrived due to the Arab Spring (Düvel \& Vollmer 2011; Frontex 2012). Most of them did not flee from direct armed conflict, but tried to get into France as economic migrants. Stopping migrants' wave, Italy and Tunisia signed an agreement, so the number of the migrants started to decrease slowly, but in 2012 still 28,000 Tunisian were registered in Lampedusa by the Italian authorities (Altai Consulting \& UNHCR 2013; Frontex 2013; Monzini 2013). Despite this, more than 40,000 refugees arrived to Lampedusa, Sicily and Malta from other African states (Fargues \& Bonfanti 2014; Monzini 2003). ${ }^{19}$ After the fall of the Kaddafi regime, number of migrants have decreased, then in 2013-2014 it started to increase again. In 2014, 170,664 immigrants arrived only to Italy, which means 277 per cent increase comparing to the data of 2013. This was a serious challenge not only for border guards but for the government and local inhabitants, as well (Frontex 2015b). Perhaps it is due to the European Union's maritime border guarding operations that the number of migrants arriving through the sea have decreased by almost 20,000 individuals in 2015. The trends of illegal migrants arriving through maritime route to Italy is shown in Figure 4.

\footnotetext{
17 Saving migrants became a special branch of industry, as the camps for illegal migrants are controlled by different militias and armed groups - even radical Islamists - instead of the weakening central government. Neither the UN, nor the NGOs have insight to most camps or any ability of supervision. Migrants rescued from the sea are transported directly to these camps, and let out only in that case if they come to an agreement with the supervising group or the smugglers in connection with them on the ways and prices of further travelling. Even though through this method, smuggler units have a secured income from migrants, many time they attack or kill the individuals.

18 The number of illegal migrants increased significantly in the country. According to the data of April 2015, the biggest groups were Syrians $(134,089)$, Sudanese $(25,055)$, Somalis $(6,524)$ and Iraqis $(6,449)$. A growing number of these groups try to ship to Italy. In 2014, 9 per cent of the arriving ships were from Egypt.

19 Italians notice the migratory wave regularly, even though they are considered as a transit country. Their country is only a "gate to Europe" and most migrants want to travel further inside the continent where their communities (e. g. Syrians in Sweden, Turkish and Kurdish in Germany, etc.) are well organized and are able to support their integration. It is proven that Italian charity organizations help migrants to leave Italy without registration, so neglecting the Dublin regulations, migrants start registration procedure in other European countries. Affected states try to find an adequate response against the renitent Italy.
} 


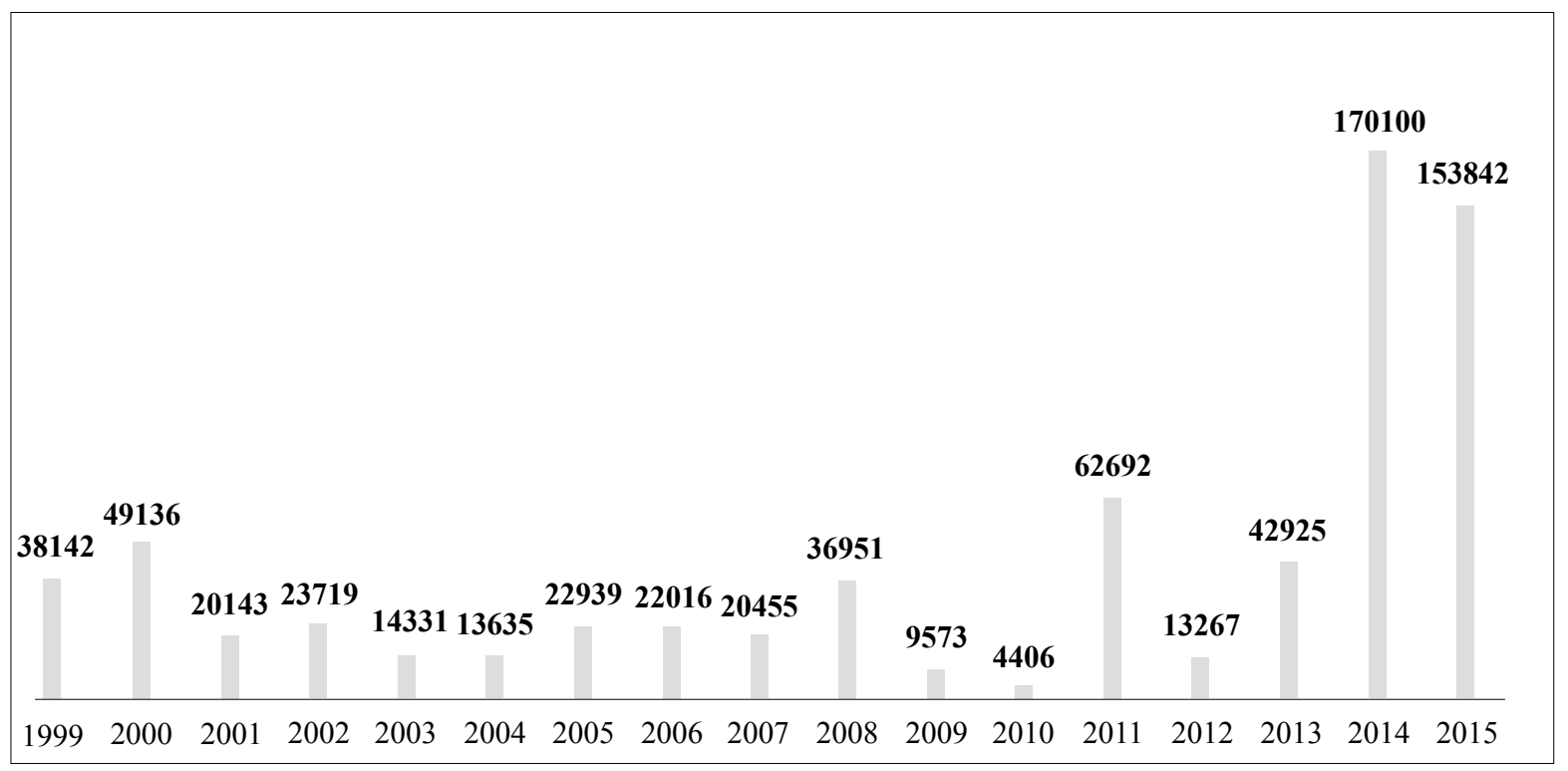

Fig. 4. Illegal migrants arriving through the sea to Italy 1999-2015

Sources: Altai Consulting \& IOM MENA Regional Office 2015; De Bruycker, Di Bartolomeo \& Fargues 2013; De Haas (2007); Global Initiative against Transnational Organized Crime 2014; UNHCR 2016; UNODC 2013

As Figure 5 indicates, Malta faces the same problem. ${ }^{20}$ Between 2002 and 2012 16,645 migrants arrived by approximately 398 ships to the country. There was a significant decrease in 2010, but due to the Arab Spring, migrants' number increased again. As a result of the Operation Mare Nostrum, their number relevantly decreased. Due to the new migration policy of the country since 2015, less immigrants arrive or more refuse the registration and leave. This might be a consequence of the fact that more and more Syrian arrive with fake documents bought from Eastern European criminal groups. A part of them are stopped by Maltese authorities - even more get imprisoned for falsification - but the wealthier Syrians can quickly go further through the help of smugglers. Malta should be mentioned as a lucky state, as migrants do not consider it as a final destination.

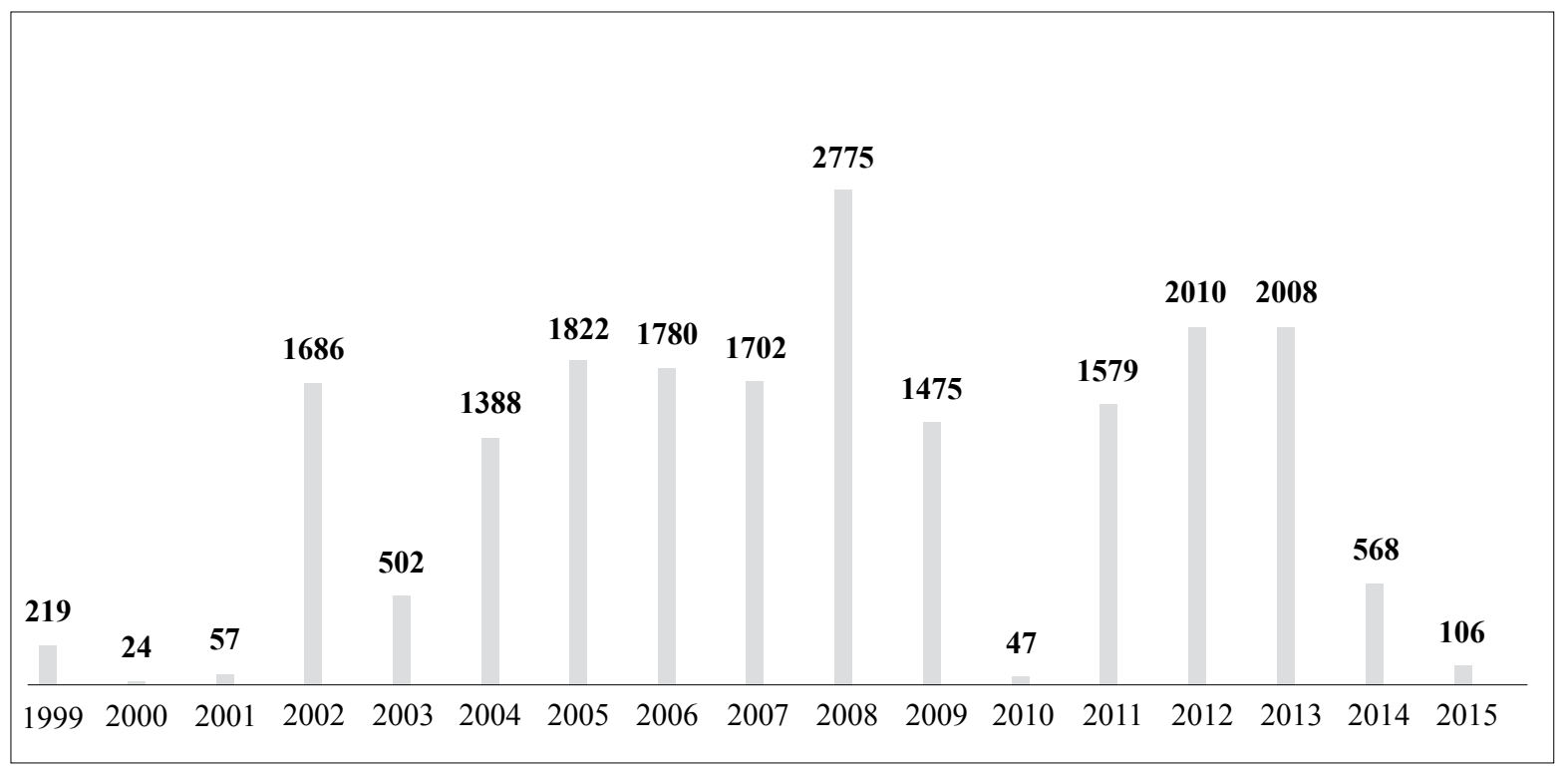

Fig. 5. Migrants arriving by ships to Malta 1999-2015

Sources: Altai Consulting \& IOM MENA Regional Office 2015; De Haas 2007;

De Bruycker, Di Bartolomeo \& Fargues 2013; IOM 2015

20 Migrants arrive to the island by ships and by planes as well. 
As Figure 6. represents, the same trend can be observed in the entire Central Mediterranean route, proving more aggressive actions, which made migrants try other routes to get into the continent (European External Action Service 2016). ${ }^{21}$

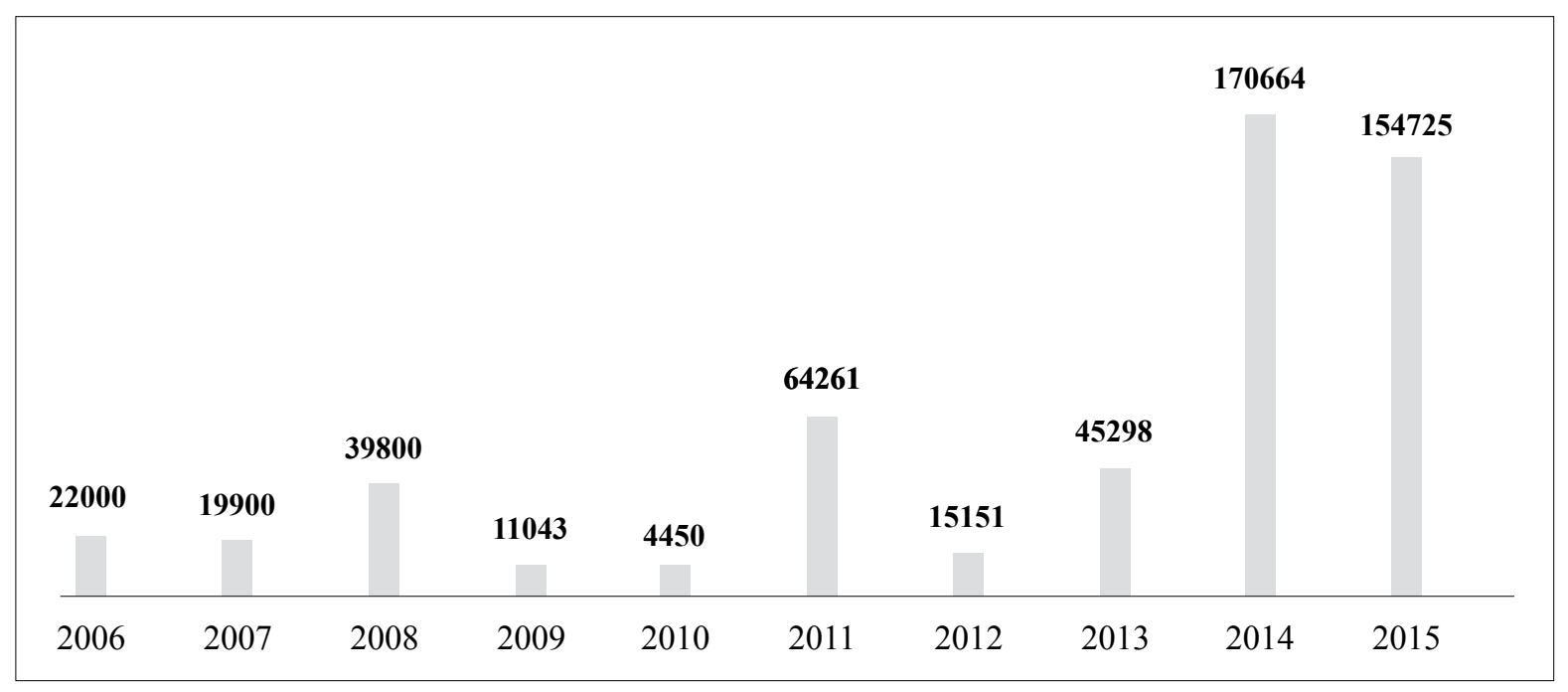

Fig. 6. Migrants arriving via the Central Mediterranean route 2006-2015

Sources: Altai Consulting \& IOM MENA Regional Office 2015; Frontex 2015b; European External Action Service 2016, Frontex 2016b

A significant part of the migrants come from Libya and Egypt to both countries. Tunisia as a departing point have lost its former role (Altai Consulting \& IOM MENA Regional Office 2015; Reitano 2015). ${ }^{22}$ Among immigrants from Libya, more and more individuals come from Eritrea, Syria and the Sub Saharan countries (Frontex 2015b). ${ }^{23}$ Some estimations claim that a migrant on his way from Agadez to the Libyan coast, pays 2,000-3,000 USD to smugglers, but getting into Europe may even cost 10,000 USD (Global Initiative against Transnational Organized Crime 2014). Same amounts are paid by migrants coming from Egypt by ships (Altai Consulting \& IOM MENA Regional Office 2015).

The states of the EU react the same way as earlier: in order to suppress migrants' wave they restrict legislation, strengthen border guards or use counter-terrorism measures. In spite of their enhanced work, they could reach only limited results (Shelley 2014). This is why the EU concentrates increasingly on the common solutions, especially in the aspects of security policy. At the end of 2014, Italy was the leader of the EU presidency. The state proposed the strengthened and extended mandate of the common European border guarding operation (EUBAM Libya) launched in 2013 (European External Action Service 2015) ${ }^{24}$ in order to be able to take more determined actions against smugglers in cooperation with the Libyan border guards (Reitano 2015). Unfortunately, this cooperation was not without conflicts. Libyan border guards were originally from the militia fighting against Kaddafi, with a hostile attitude to the European border guards and policemen. They had to be relocated to Tunisia for their safety (Parkes 2014). Finally, due to Italian pressure, in November 2014, the operation

21 According to the data from 2014, less migrants arrived to Europe via the Central Mediterranean route, but at the same time, EasternMediterranean route became more frequently used.

22 The decisions introduced by the Tunisian government (setting up checkpoints, imprisonment for illegal border crossing, etc.) decreased the number of incoming migrants radically, who rather chose Libya, so in the future, Tunisia is going to have a transit role.

23 The biggest group of registered illegal migrants is Syrian (39,651 individuals - 23 per cent of all), followed by Eritreans $(33,559$ individuals - 23 per cent) and Sub-Saharans $(24,672-14$ per cent).

24 The civil operation (EU Integrated Border Management Assistance Mission in Libya) was launched in 22. May 2013. In order to fight illegal migration and strengthen Libyan border defense, with a two-year mandate that has been extended for another two years in 2015. The annual budget of the mission was 26M EUR. The mission's tasks are mentoring, training and supporting Libyan authorities, they do not have other operative activity. Originally, it was set up in Libya, but for security reasons (such as the appearance of ISIS) it was relocated to Tunisia, and the international staff was significantly dismantled (17 individuals remained from the original 57 until the end of 2014, which was further cut to 3 individuals until March 2015). 
Frontex Plus (sooner renamed to Triton) have been launched with the participation of Finland, Spain, Portugal, Iceland, the Netherlands, Latvia, Malta, France, Romania, Switzerland, Germany, Norway, Sweden, Austria and Poland (Llewellyn 2015). This new operation was launched with seven ships, two planes, one helicopter and a monthly 2, 9 million Euro budget (Llewellyn 2015). ${ }^{25}$ The main task was the border guarding alongside Italy and Malta and the participation in the rescue of migrants (Frontex 2015b). ${ }^{26}$ Five analytical groups were organized with a task to map different smuggler networks using covert information and open source intelligence ('Frontex launches Joint Operation Triton' 2014). Although the operation reached limited results, it could not stop migrants' wave. Supplementing the needed participation and mandates, a new operation EUNAVFOR Med started in May 2015 with 22 participating nations (European External Action Service 2016). ${ }^{27}{ }^{28}$ This operation had a mandate not only to seek smugglers, but to locate, supervise or confiscate ships. As it was planned, they are able to take actions against smugglers not only in international waters, but with UN mandate, even in Libyan territory. They are not only fighting against smugglers and illegal immigrants, but rescue all those who got into trouble on the sea (Frontex 2015b; Human Rights Watch 2015; International Crisis Group 2015). During operations, until the end of 2015, 46 smugglers were captured and 67 ships were confiscated, so the smugglers activity was limited at Libyan waters. According to the mission commander, later it will be necessary to act directly against smugglers, but it still have political and legal barriers (European External Action Service 2016). EU created EUROSUR, too. This is an integrated reconnaissance and intelligence system for monitoring migrants and smugglers crossing the Mediterranean Sea (Brian \& Laczko 2014). The increase in the number of immigrants, unfortunately means an increasing number of drown individuals during illegal border crossings (Brian \& Laczko 2014). Some experts of migratory trends claim that five to ten per cent of the boats departed from Libya sink on their way across the sea (Altai Consulting \& UNHCR 2013). A report of the Bilgi University of Istanbul states that 34,000 migrants died between 1989 and 2009 in the Mediterranean and the Aegean Sea (Borelli \& Stanford 2014). According to a UNHCR report, at least 35,000 illegal immigrants have drown only in 2014 during their way to Europe. Only in the second week of September more than 500 migrant drowned. According to an independent Italian organization, Fortress Europe's research, 21,439 migrants died between 1998 and 2014 in the Mediterranean Sea. The organization highlights that the chance for drowning is nearly 2, 1\% (Del Grande 2016). ${ }^{29}$ The International Organization for Migration estimates that the number of lost individuals increased up to 22,400 for May 2015 (Human Rights Watch 2015). This growth is significant compared to the data of 1998-2002 when this number was only 0, 4\% (Fargues \& Bonfanti 2014) or to 2003 (almost 1\%) (Monzini 2003). According to another study, thirty out of every thousand migrants, who arrive across the sea, lose their life, so the chance for drowning can reach up to 3\% (De Bruycker, Di Bartolomeo \& Fargues 2013).

One of the most notorious event was in October 2013 when more than 360 migrants died at Lampedusa as their ship's motor burned out. There were more than 500 migrants on board in the small (20 metres long) ship. Most of them died by trying to escape (Brian \& Laczko 2014; Global Initiative against Transnational Organized Crime 2014; van Reisen, Estefanos \& Rijken 2013). Due to the enormous international and domestic pressure, the Ital-

25 The operation was started by Italians, Maltese and Icelanders with limited activity, in which 65 officers took part with 12 military vehicles (naval and air). Other countries joined later.

${ }^{26}$ Smugglers take an advantage of cramming more people in the ships than it would be safe, or not giving them sufficient fuel or food. After launching the ships, they report the ship to the authorities, who then are forced to rescue on their own cost. It may happen that operatives arrive too late and the ships are sunk.

27166 individuals serve at the HQ of the operations: 113 Italians, further 53 from Belgium, Bulgaria, Cyprus, Czech Republic, Estonia, Finland, France, Germany, Greece, Hungary, Latvia, Lithuania, Malta, the Netherlands, Poland, Slovenia, Spain, Sweden and the United Kingdom. The operations HQ of the mission is on the "ITS Garibaldi" battleship. Currently there are more than 1300 individuals serving in the operation. In the first phase (from July to 15th September) alongside "ITS Garibaldi” the „ITS CAVOUR” (with EH101 MPRH helicopters), the „HMS ENTERPRISE”, the „FGS SCHLESWIG-HOLSTEIN” and the „FGS WERRA” ships took part in the mission. Furthermore Luxemburg sent MERLIN III airplanes, and the United Kingdom deployed an EH101 Merlin MPH plane to Malta to strengthen reconnaissance abilities of the operation. During this period, operatives rescued 3,078 migrants from the sea. In the second phase (,2A- High Seas”/ 28th September till the end of December) the following ships joined: „FS COURBET”, „SPS CANARIAS”, „BNS LEOPOLD I”, „HMS RICHMOND”, „PC TRIGLAV” alongside more airplane and drones helped the personnel. The forces of EUNAVFOR Med consisted of 9 ships, 1 submarine, 3 airplanes, 5 helicopters and a drone. During the second phase 8,336 migrants were saved out from the sea, 67 ships were destroyed and 46 smugglers were intercepted and imprisoned in cooperation with the Italian authorities.

28 Also known as „Operation Sophia”

29 These are the registered cases. According to the organization, much more people die when they try to cross the sea. 
ian Letta government launched operation „Mare Nostrum” on $8^{\text {th }}$ October 2013, in order to secure the Mediterranean Sea and to decrease the chance of maritime catastrophes (Reitano 2015). During the operation, five vessels with 1,500 seaman were in patrol in international waters between Northern Africa and Sicily. The operation was supported by two submarines, five aeroplanes, two helicopters and drones. The Slovenian government provided one ship to help the Italian Navy (Llewellyn 2015). The total cost of the one year mission was 114 million euro, from this 30 million was provided by the EU. Italian sailors rescued 160,000 migrants, escorted more than 600 ships to safe haven, confiscated nine smuggling carriers, captured and prosecuted 330 smugglers. The mission ended in $31^{\text {st }}$ October, 2014. Its mandates were taken by "Operation Triton" controlled by Frontex (De Bruycker, Di Bartolomeo \& Fargues 2013; Frontex 2015b; Kuschminder, De Bresser \& Siegel 2015). "Mare Nostrum" was successful, because in winter 2013 and spring 2014, due to the operation of the Italian Navy, less people lost their life during the sea-route. Despite this, many critics mentioned that its success lead to the increasing number of illegal migrants, because smugglers towed their overloaded and poor-conditioned ships near to the Italian navy vessels and let them rescue migrants (Altai Consulting \& IOM MENA Regional Office 2015; Fargues \& Bonfanti 2014). Partly this, partly different causes explain why the operation was finished at the end of 2014. Living up to the need for international control, EU launched „Joint Operation Triton” in November 2014 (Human Rights Watch 2015). This operation was a continuation of „Mare Nostrum” and the former Frontex operations (Hermes, Aeneas) (Llewellyn 2015). Though the expenses and resources were divided between the participant countries, the new operation's abilities were significantly less than a common EU operation's mandates. Besides Triton, Italy initiated individual operations, (Llewellyn 2015) (30 $^{30}$ and similarly did other European countries (Germany, France and the United Kingdom) with the supervision of merchant ships. Simultaneously, NGOs and civilians actively helped in rescuing people. Despite these activities, still many migrants die in the waves, in April 2015, 900 individuals lost their life in a weekend (Altai Consulting \& IOM MENA Regional Office 2015; Llewellyn 2015). The trends of the numbers of drowned migrants in the Mediterranean Sea are indicated in Figure 7.

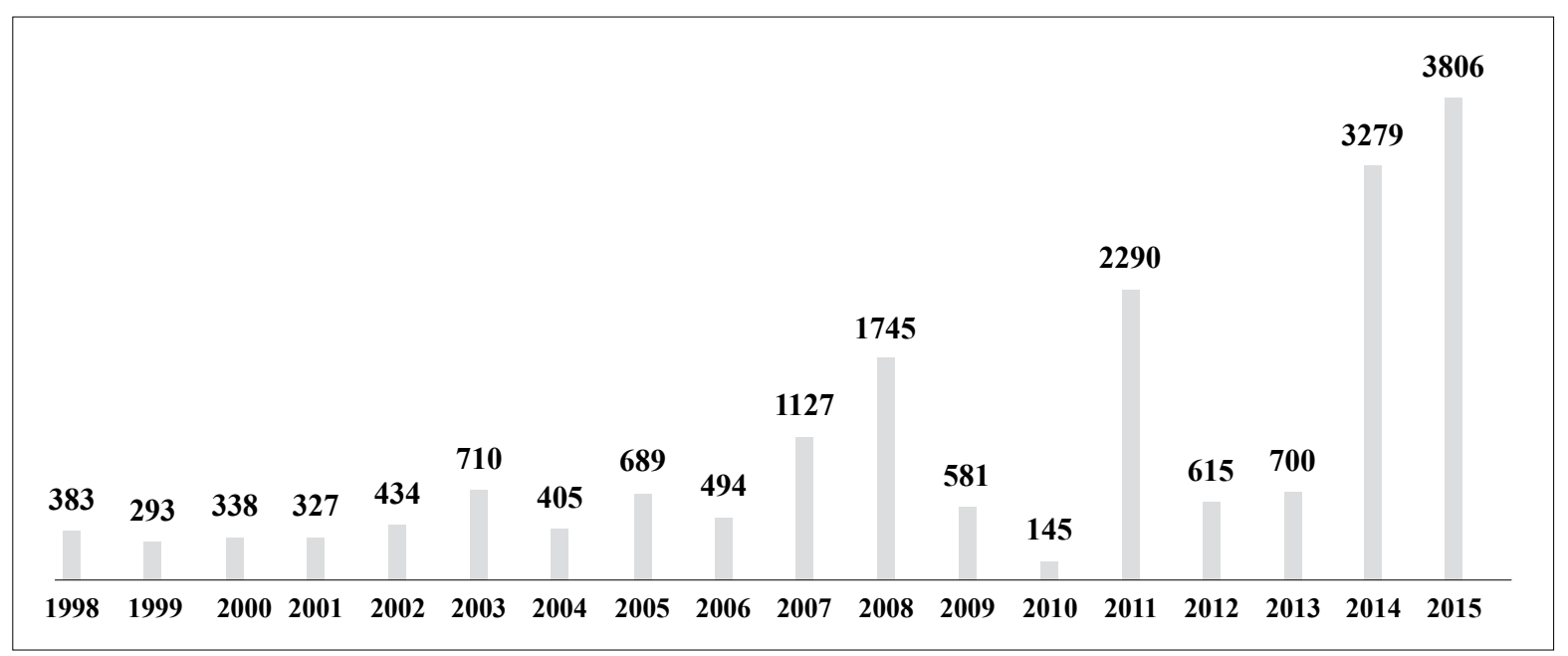

Fig. 7. Numbers of drowned migrants in the Mediterranean Sea 1998-2015

Sources: Human Rights Watch 2015; Del Grande 2016, Altai Consulting \& UNHCR 2013; Brian \& Laczko 2014; UNITED Against Refugee Deaths 2015, Missing Migrants Project

According to a report of Frontex in 2015, the biggest migratory waves are expected to arrive via this and via the eastern Mediterranean route, so the border guards must be reinforced (Frontex 2015b). Last year's events confirmed the forecast, since there was a significant increase in the traffic on this two routes. The central Mediterranean route lost its leading position and the eastern route turned out to be important (European External Action Service 2016).

\footnotetext{
30 The Italian coast guards have cca. 300 ships in 3 naval and 113 civilian ports. Considering migratory challenges, a special unit have been set up in Lampedusa in 1994, equipped with modern rescue ships. Unfortunately, these ships can only carry a few people, which is disadvantageous in a rescue action. This was proven on 8th February, 2015. when 22 migrants died in an action, because ships needed seven hours to find the migrants in the sea. Seven of them were drowned by then. After rescuing survivors, it took 18 hours for them to get back to Lampedusa. During this time, further 15 individual died despite the medical help. Considering this experience, Italian coast guards decided further improvements.
} 


\section{Eastern African route}

This route does not lead directly to Europe, but to the northern African region, where migrants come from Eritrea, Ethiopia, Djibouti and Somalia via Sudan, Egypt and Libya. Trying to reach the European continent mostly using the Central Mediterranean route, migrants from eastern-Africa gather (Global Initiative against Transnational Organized Crime 2014). The route launches in Somalia, where migrants cross the city of Wachalah at the border, then firstly get to the Ethiopian capital, Addis Ababa, where they can choose between three different routes to Khartoum. The first one leads from Addis, crossing the Sudanese borders at Metema, via Gellaba where they are placed in nearby refugee camps. When meeting the sufficient conditions they leave for Khartoum. The second one leads from Addis to Humera in Sudan, from where migrants are transported directly to the capital. The third way is the most secure one, but it is only for Ethiopians, since an agreement between Ethiopia and Sudan allows them to use the airways to Khartoum and are allowed to stay for two months by tourist visa. Researchers estimate that 50 to 100 Ethiopian migrants cross the Sudanese border using this opportunity (Altai Consulting \& UNHCR 2013).

Eritrean migrants start from Asmara and Massawa via Tasseney and Guluj to the Sudanese Kassala and ElKedarif, then to Khartoum (van Reisen, Estefanos \& Rijken 2013). ${ }^{31}$ From here they move on with the help of smugglers through the Sahara, crossing Dongola and Uweynat, until they reach Kufra in Libya (Altai Consulting \& UNHCR 2013). Most of them spend months or years in the UN controlled refugee camps until they are ready to move on. Earlier, some migrants arrived through North Darfur (Nyala, El-Geneina and Milit), but after the Darfur genocide, the route became almost abandoned, ${ }^{32}$ only some smuggling groups used it (Kuschminder, De Bresser \& Siegel 2015). In Libya, one big transit- and collecting point was Kufra, where monthly ten to twelve thousand migrants were stationed in the city. Due to the violent affairs between the Tebu and Zway tribes, their amount was decreased to 1-3,000 individuals (Reitano 2015). ${ }^{33}$ Besides, another reason is that thanks to the increased military presence - smugglers bypass the city, and try a new route via Rebiana, Tazerbo and Ajdabiya (Altai Consulting \& UNHCR 2013). By the way, the ten days long Khartoum-Kufra route is the most dangerous, because migrants have to cross the Sahara desert. Another alternate path crosses the Egyptian border at Jaghbub from Khartoum to the Libyan Tobruk via Dongola. From Tobruk, migrants can easily reach Libyan ports. On the basis of the visa-free travel, a part of Sudanese migrants fly to Cairo, then try reaching Libyan ports via Salloum-Um Saad and Tobruk. Syrians use the same way combined with bribing Egyptian customs officers to get into Libya (Altai Consulting \& IOM MENA Regional Office 2015).

Nobody knows, how much does it exactly cost for a migrant to get to Libya or Tunisia, but there are many different estimations. According to the Regional Mixed Migration Secretariat's estimates an amount of 1,000 USD must be paid for smugglers and 1,000-2,500 USD more for crossing the Mediterranean Sea (Regional Mixed Migration Secretariat 2013). As the above mentioned regions send only 2,2\% of migrants, some researchers expect the increase of this rate for the upcoming years, at least for the fact that there are millions of hopeless people living in the Eastern African refugee camps, ready to leave for Europe at every minute (Martín \& Bonfanti 2015).

\footnotetext{
31 Transporting Eritrean migrants is almost a monopoly of the Rashaida Arab tribe, who sometimes kidnap them, for ransom. These migrants can only continue their travel after they paid. To maintain the profitable business, 30-50 abductions are executed in a month. The real number might be higher, as migrants have no interest in turning to the authorities. An average of 5,000 Eritreans arrive to Sudan every month via this route, so the mentioned tribe has a remarkable income from smuggling.

32 I spent a lot of time in the area of operations during my service as a logistics advisor in Darfur mission of the African Union in 2005. Happened once, that in the nearby the city of Milit in the South African sector, we met a crowd of 2-300 individuals travelling with Toyota pick-ups and other trucks, heading to Chad. Our Sudanese interpreter told me that they were a group of Somali and Ethiopian migrants, guided by the local Zaghawa tribe. The local interpreter claimed that more groups cross the area every week, but, due to the recent events, their amount is in decrease. I met similar groups at the Chadian border, in the city of Tine, where AU also had a military camp under my responsibility, so I was not a rare visitor in that region.

33 There are more and more small armed conflicts between Tuaregs and Tebus, who make an increasing amount of profit from smuggling. Besides, they earn new territories against other tribes in the "Salvador triangle".
} 


\section{Apulia (Puglia) - Calabria route}

This route is leading across Egypt and Turkey towards Italy and Greece. Most of the migrants come from Asia (Afghanistan, Pakistan, Bangladesh and Syria) and enter the Schengen area at the Turkish-Greek border (Brian \& Laczko 2014; Monzini 2003). A significant part of the refugees lived in Greece for years, but due to the world economic crisis and the Greek political and economic situation, they try to reach the inner parts of Europe. Migrants use mostly maritime routes by ships of different smuggling networks to get to Europe (Frontex 2015b). Smugglers' tools can be very different: everything occurs from fast and modern yachts until inflatable boats and dinghies. Organized smuggling groups transport migrants with fast ships, hidden in the low deck, in order to avoid helicopter patrols' attention. These ships are formed to be able to carry as many people as it can. Because of the design, the crowd travels very uncomfortably, but safer than it would be in a smaller ship. Egyptian smugglers have a different method. The human traffickers of frequently used routes apply liners or freights surrounded with smaller fishing boats. As soon as they see the European coast, migrants are transferred to the smaller boats that disembarks them in different places, the "mother ship" returns to Egypt for new passengers (European External Action Service 2016). In this case, the chance for being caught is much smaller, because border guards cannot efficiently intercept - if they can even discover - migrants fleeing in different directions. Anyone who reach Italian shores, is able to apply for refugee status.

Migrants' primary goal is the South Italian regions of Apulia and Calabria, which are favourite destinations of illegal migrants since the 1990's, especially for those who come from Balkan states (Monzini 2003). ${ }^{34}$ Through Apulia region migrants arrive to Italy from Greece by crossing the sea, besides routes from Montenegro and Albania by crossing the Otranto Channel are also important to mention. Calabria is a target for those who come from Egypt and Turkey to Italy. The number of arriving immigrants increased from the mid 1990's, but turned to slow decrease from 2002 until 2011. After the Arab Spring it started to increase again, despite that many migrants chose the less risky Western Balkan route. After the outburst of the Syrian civil war, more and more migrants used this path, especially Syrian refugees from Pakistani, Egyptian and Turkish refugee camps (Reitano 2015). ${ }^{35}{ }^{36}$ In the recent two years, the number of migrants increased to such an extent that Turkish smugglers in the port of Mersin started to use bigger ships - that are capable to carry 600 passengers in average. Figure 8 shows us the development of migrants using the Apulia - Calabria route.

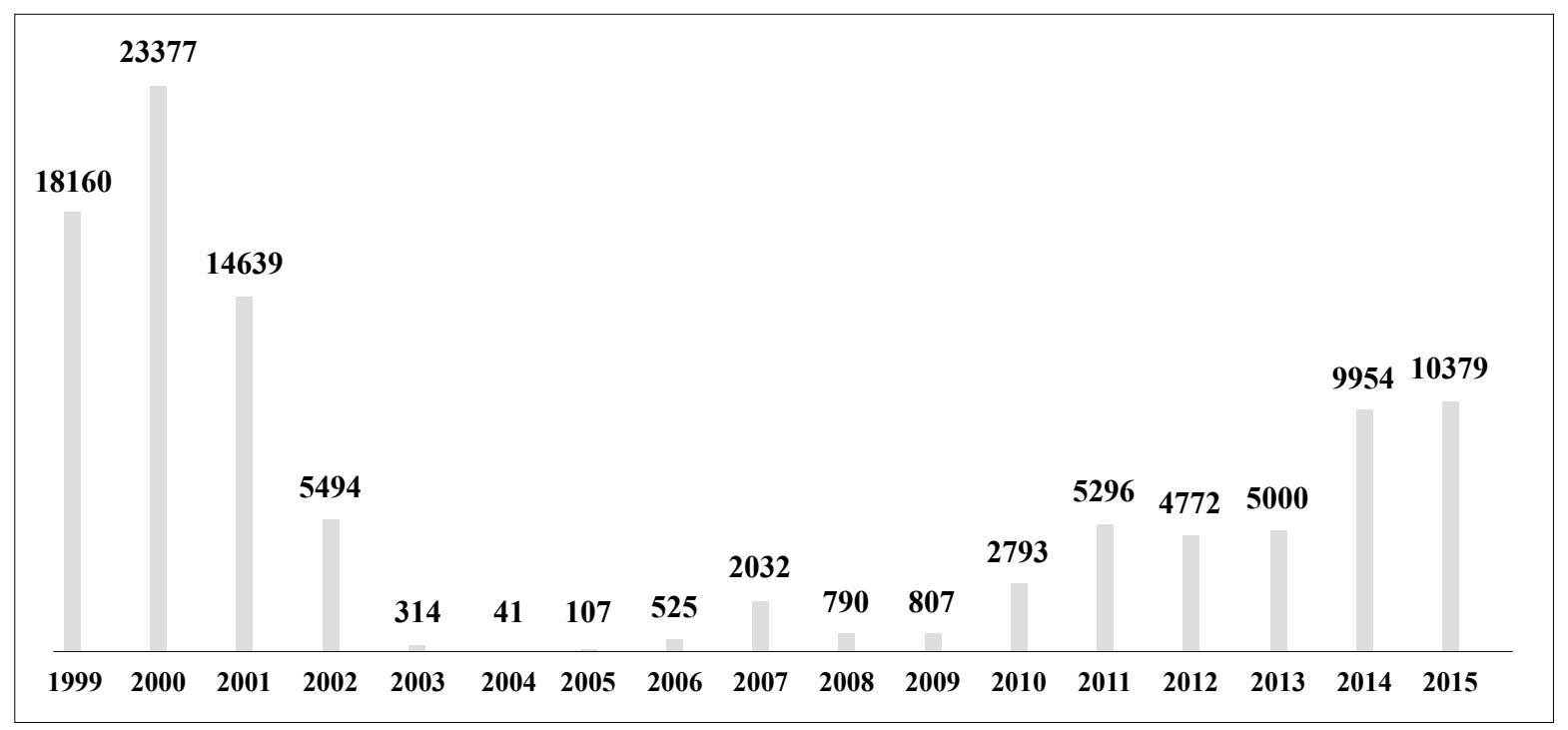

Fig. 8. Migrants arriving via Apulia-Calabria route 1999-2015

Sources: Fasani 2009; Monzini 2003; De Bruycker, Di Bartolomeo \& Fargues 2013; Ministero dell'Interno 2014; Ministero dell'Interno 2015

\footnotetext{
34 This is partly a consequence of the stabile historical and social background of organized criminal groups (e. g. ndrangheta) in this region. Additionally, they take part in human and drug smuggling, prostitution and other different illegal activities.

35 Many refugees arrive via this route from Somalia, Eritrea, South Sudan and the Democratic Republic of Congo.

36 According to the different reports, the biggest group of immigrants in Europe are Syrians, whose amount is growing rapidly (similarly to the number of Eritreans).
} 
Local smugglers demand 6,000 EUR from Syrians who try to get to Europe, but these refugees may not hope mercy from the thundery sea, rivalling smuggling groups or the border guards of European countries ${ }^{37} \mathrm{Re}-$ cently, a new threat appeared: the Islamic State (IS). It does not only realize profit from smuggling, but there are demonstrable signs of their intention to hide their own people between refugees to get them into Europe.

\section{Western Balkan route}

This is the third busiest route (Frontex 2015a; Frontex 2015b), where alongside contrabands (such as weapons, drugs, fake branded goods etc.) we can mention two main groups arriving to the EU (Shelley 2014). Firstly, western Balkan states' residents (from Albania, Serbia, Bosnia-Herzegovina, Kosovo, Macedonia and Montenegro) and secondly, Asian or Middle Eastern migrants who arrive through the Bulgarian-Turkish and GreekTurkish borders, then trying to get to Austria, Germany or the northern countries via Hungary (Kuschminder, De Bresser \& Siegel 2015). Besides, this route manages the most Syrian and Somali migrants. Those who arrive to Macedonia, smugglers transport them by taxi cabs to the Serbian borders. For a long period this route was mainly used by illegal migrants from West Balkan states who were heading to European countries (Frontex 2015a), ${ }^{38}$ but recently these states' citizens (except Kosovo) can travel without visa in the EU, so their number decreased significantly. Simultaneously, number of illegal migrants from Kosovo (especially Albanians) increased. In the beginning of 2014, monthly 1,000 Kosovan arrived via this route, since September this amount increased to 9,000. Some think that the trend changed in connection with the rumours that France wanted to exclude Kosovo from the list of safe countries. In that case, Kosovan economic migrants could earn refugee status in western countries (Frontex 2015b). Later it was revealed that the assumptions were a hoax and France never thought about the step above, so Kosovans do not get refugee status but will be sent back as soon as possible.

The Hungarian government had serious problems with the growing crowd of arriving migrants. In 2009 they were coming mainly from Kosovo (Frontex 2010a), but in 2012 migration became more ,international”. The next year an unprecedented migration crisis developed. Almost 20,000 immigrants entered Hungary illegally and applied for refugee status in 2013. Most of them were Kosovans, but there were Pakistanis, Afghans, Moroccans, Algerians and Sub-Sahrawians. This was the moment when Hungary strengthened its border guards and introduced a new regulation on refugee status applications from $1^{\text {st }}$ January, 2013 (Frontex 2014). This was not followed by a radical decrease in illegal migration. In July 2013, 130 illegal migrants were caught on an average day. They were taken to registration points, from where they immediately headed to Austria or Germany and applied for refugee status in those countries. ${ }^{39}$ The number of migrants decreased appreciably in the second half of the year, but since 2014 there was a significantly emerging number of refugees from Turkey. Hungarian authorities tried to reduce it with different instruments. ${ }^{40}$ According to a Frontex report 43,357 illegal migrants were registered in 2014, that means a significant, 46 per cent increase. Illegal migrants were mostly Kosovans (22,059 individuals), Afghans (8,342 individuals) and Syrians (7,320 individuals).

The increase in the number of migrants tended to be permanent in 2015, when most of them arrived via Greece and Hungary, and kept these governments' administration overwhelmed. As Figure 9 indicates, in 2015, eight-

\footnotetext{
37 Smugglers only care about the profit. That is why they are trying to cram as many migrants as possible into big but old ships that are not eligible for maritime shipping. Many times the Automatic Identification System (AIS) is turned off, so the ship cannot be recognized electronically. Many times it happens that smugglers turn on autopilot and leave the boat and refugees on their fates. They can only hope in survival.

38 In 2012, approximately 33,000 refugees arrived from Western Balkan states to Europe. This is 53 per cent higher than the year before (2011), and means 12 per cent of all refugee applications in EU countries. I also have to mention, that arriving migrants are not likely to return after their visa expires.

39 There is no such big or well organized Islamic community in Hungary which could provide stabile background for migrants, so most of them do not want to stay even temporarily. Unlike Hungary, we can find strong networks in Austria, Germany or Benelux states, which often help migrants' settlement for a short period of time, and continue their travel to their real destinations (northern states, United Kingdom, etc.).

40 Different provisions (blockades, restrictions of border control, suspending visa-free travelling, deportation of illegal migrants, etc.) cannot stop migratory waves, but they have role in forming the migratory routes. The direction of the route might change and thereby migratory pressure on a country can be significantly decreased. These results, however are only temporary, and changes can be influenced by decisions of the neighboring states.
} 
een times more migrants arrived via this route than in the previous year (Frontex 2015a).

The development of the number of migrants between 2009 and 2015 is shown below.

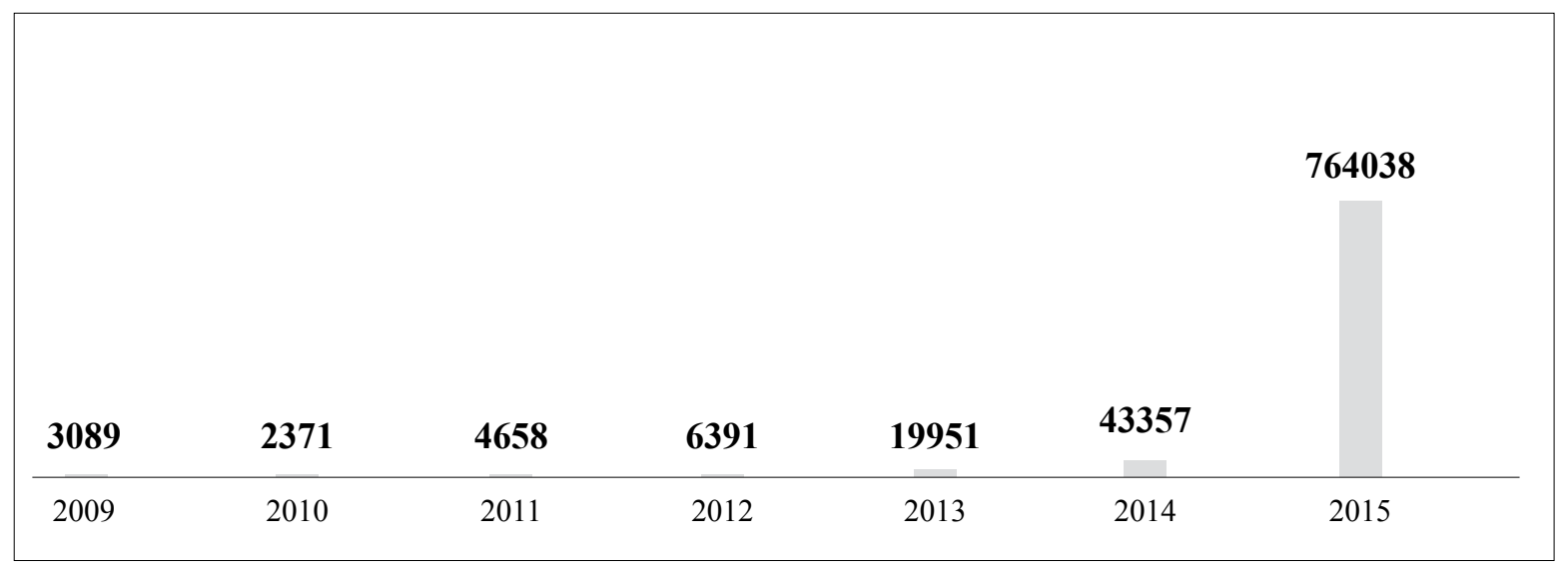

Fig. 9. Migrants arriving via the Western Balkan route 2008 - 2015

Sources: Frontex 2015b; Frontex 2016b

\section{East Mediterranean route}

This route is frequently used by illegal migrants who are leaving Turkey and via Greece, Bulgaria and Cyprus, trying to get into the EU. Since 2008 this has been the second most popular direction - this way provides 18 per cent of them (Brian \& Laczko 2014; Kuschminder, De Bresser \& Siegel 2015) - and their number grows permanently (Schapendonk 2012). Smuggling networks, operating mainly in Istanbul, Izmir, Edirne and Ankara, have members of various nationalities (Syrians, Somali, Afghan, Pakistani etc. alongside Turkish) (Reitano 2015). Most of the migrants arrive from Syria, Somalia, Afghanistan and Pakistan, and in the recent years, the rate of Sub-Sahrawians increased (Schapendonk 2012). Thanks to the visa-free travel, these countries' citizens can legally travel to Turkey, from where Africans can go further by the help of smugglers. Their amount reached 40,000 individuals in 2008 and 2009, giving forty per cent of arriving migrants to Europe. Since Greek border authorities patrolled carefully and regularly, migrants chose terrestrial ways instead of the highly checked sea routes. In the summer 2010, migrants arrived through the Turkish-Greek border river Evros in a bigger amount than ever before. The passengers were mostly from Iraq and Afghanistan and their number increased permanently (Kuschminder, De Bresser \& Siegel 2015). In October 2010, at least 350 illegal migrants were caught by the Greek border guards near the city of Orestiada. As the situation developed, Greece asked for the help of the common European authority, the Frontex in order to stop migratory wave (Frontex 2011a). Frontex sent a Rapid Border Intervention Team (RABIT) in November 2010 in order to help Greek authorities (Dimitradi 2016; Frontex 2010b; Frontex 2011a; Frontex 2011b). ${ }^{41,42}$ It was only a temporary solution as during 2011, more than 57,000 illegal migrants crossed the Greek borders. Greek authorities introduced new, stricter measurements ${ }^{43}$ and launched the Operation Aspida. Within the framework of the operation, police units and modern devices (thermos cameras, night vision gears, etc.) were deployed to the Evros region, and a 12,5 km

\footnotetext{
41 The special quick response unit of the Frontex contains 672 border guards and policemen from 27 EU member countries. A group of 191 individuals were sent to Greece, who served from November 2010 to 2nd March 2011. on the Turkish-Greek border and intercepted 11,809 illegal migrants and 34 smugglers. At the end of the mission, decrease in the number of arriving migrants reached 76 per cent.

42 Both Greek government and Frontex command were satisfied with the results of RABIT unit. The organization proposed to set up a same unit with 1,500 individuals in the beginning of 2016. Important detail of this proposal is that the newly formed unit is deployable to every member country's border, even without the permission of the concerned state. Due to political and legal difficulties, it is still not applicable.

43 In order to quicker the progress, camps were established for intercepted illegal migrants, their deadline for residence was limited, as well as the refugee applications procedure. Migrants, who were not willing to move into camps, were allowed to stay for only 7 days in the country, instead of the earlier 30 days.
} 
long wall was built near Orestiada in order to limit migrants' movement. The authorities controlled the ports of Patra and Igoumenitsa intensively, keeping migrants under pressure. Adapting to the changes, the migrants left for Italy and other European countries. As a result of the operation, border guards realized a significant decrease in the number of illegal migrants in Greece (Frontex 2014). Despite these efforts, there many people stayed illegally in the country, so another operation „Xenios Zeus” was launched to detect and expel illegal migrants (Frontex 2013). ${ }^{44}$ Greek and Turkish border guards started a closer cooperation, resulting in a decrease of the number of migrants to 6,000 (Frontex 2015b). In 2014, migrants rather used Bulgarian-Turkish border (Reitano 2015) ${ }^{45}$ or tried to enter the EU in marine routes instead of the Greek territories (Brian \& Laczko 2014; Fargues \& Bonfanti 2014). Indeed, there were migrants who tried to travel to Italy directly through the sea from Turkey, and many European country highlighted that many arriving passengers had fake documents at international airports, too. Despite the introduced measurements, the number of migrants increased in 2013, indeed, Bulgaria was overran by Syrians who came through Turkey. This situation deteriorated in 2014, as compared to the previous year, twice as much migrants arrived, mostly by ships through the Aegean Sea (Frontex 2015b). ${ }^{46}$ The increase in the number of migrants coming via the East Mediterranean route in 2015 surprised everyone, as compared to the previous year, indicated in Figure 10, sixteen times bigger crowd arrived. This was a number, which no one was expecting before (Frontex 2015a).

Figure 10. shows the development of the number of migrants on this route between 2009 and 2015

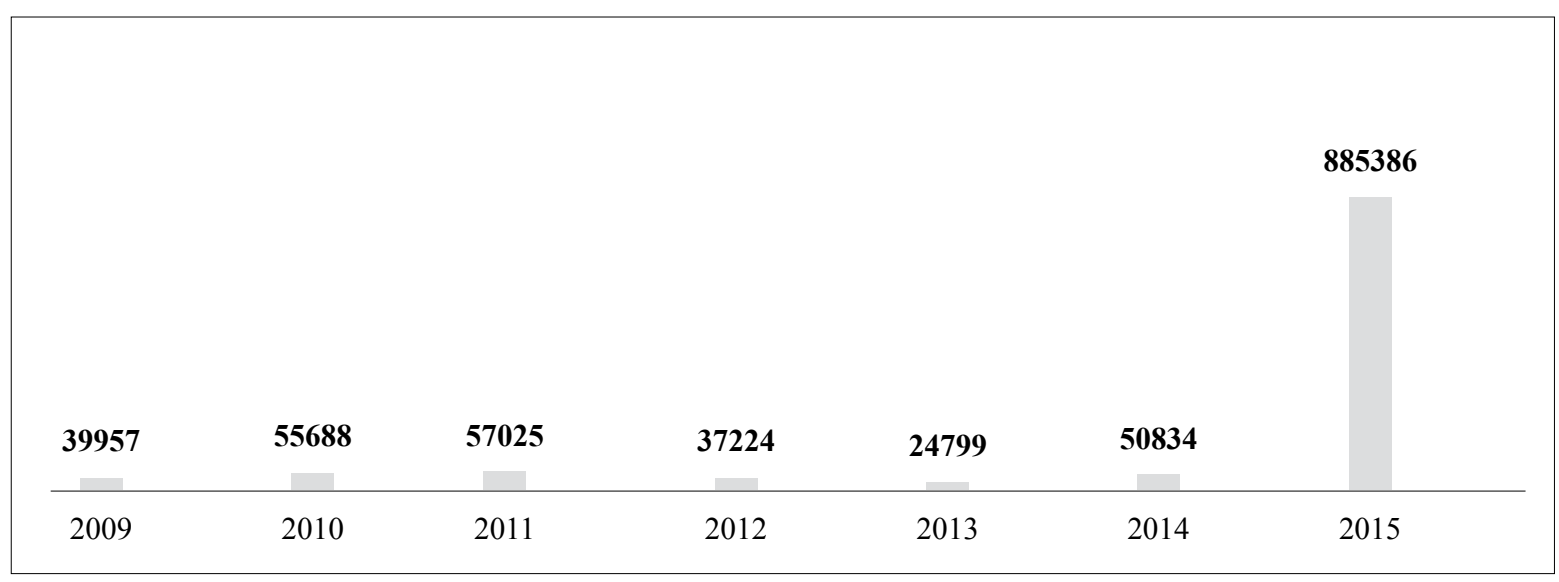

Fig. 10. Migrants arriving via the East Mediterranean route 2009-2015

Sources: Frontex 2015a; European External Action Service 2016; Frontex 2016b

We have diverse data on the migrants' expenses, but according to estimates, the route costs approximately 2-3,000 EUR for those who come from the East and West African countries, and 1-1,500 EUR for NorthAfricans to travel from Turkey to Greece and an additional 2,500-3,000 EUR for being smuggled into Italy (Kuschminder, De Bresser \& Siegel 2015).

\footnotetext{
44 In this operation 1,881 policemen were sent as reinforcement to the Greek-Turkish border. At the mentioned territory, a more determined step against illegal migrants took place with increased capacity of identification points, thereby enabling the residence of more migrants at a time. Cooperation with Turkish authorities were also invigorated, so the number of illegal migrants decreased significantly in this area until August 2014.

45 The EU supported the building of a $33 \mathrm{kms}$ long fence on the Turkish-Bulgarian border in order to prevent illegal migration.

46 According to a Frontex report 24,799 illegal migrants were registered via this route to Europe in 2013. In 2014 this number increased to 50,834. 62 per cent of the migrants were Syrian, 25 per cent Afghan and 3 per cent Somali. According to the reports, 87 per cent of migrants arrived on marine routes.
} 


\section{Route across the eastern borders}

The EU have 6,000 km long ground borderline with Belarus, Moldova, Ukraine and Russia, which is not only a challenge for historical reasons but also pose other risks for the authorities (Frontex 2015a; MIGREUROP 2010). Thanks to the well-organized networks, illegal migrants and smuggled goods can reach EU territories on the "green border" almost unchecked. Most of the migrants come to Hungary, Slovakia and Poland from Ukraine, via Kiev and Uzhhorod, and most of them travels further to the western states (Düvel \& Vollmer 2011). Thanks to the relatively small number of arriving migrants, this route was out of sight, but in 2012-2013 their impact on European migrant networks grew. The migrants came particularly from Russian Federation, their Asian, Middle Eastern states or Somalia (Frontex 2013; Shelley 2014). This growth was significant especially on the Polish-Russian border, where the rate of arriving migrants has increased with 70 per cent, but the same tendencies were seen on the Norwegian-Russian, Finnish-Russian and the Polish-Ukrainian borders. In 2013, a bigger group of Georgian refugees appeared at the Polish-Belarusian border and left almost immediately to Austria, Germany and Belgium. In 2014, despite the outburst of the Ukrainian conflict, the number of illegal migrants remained the same, we have data about only 1270 individuals (Frontex 2015b; Kuschminder, De Bresser \& Siegel 2015). Figure 11. indicates that this route is the less frequented among all. According to Frontex yearly reports, only about 1,000 illegal migrants arrive via this route, which covers about 2 per cent of the entire migration to the EU. This might change in 2016, since migrants consider this route important on their blogs as a new possible way to the EU, where - thanks to the uncertainty generated by the Ukrainian conflict, insufficient control above borders and corruption - they can get through easily. Additionally, they hope that Poland may not stop migrants heading to Germany.

The progress of the number of migrants on this route between 2009 and 2015 is shown in Figure 11.

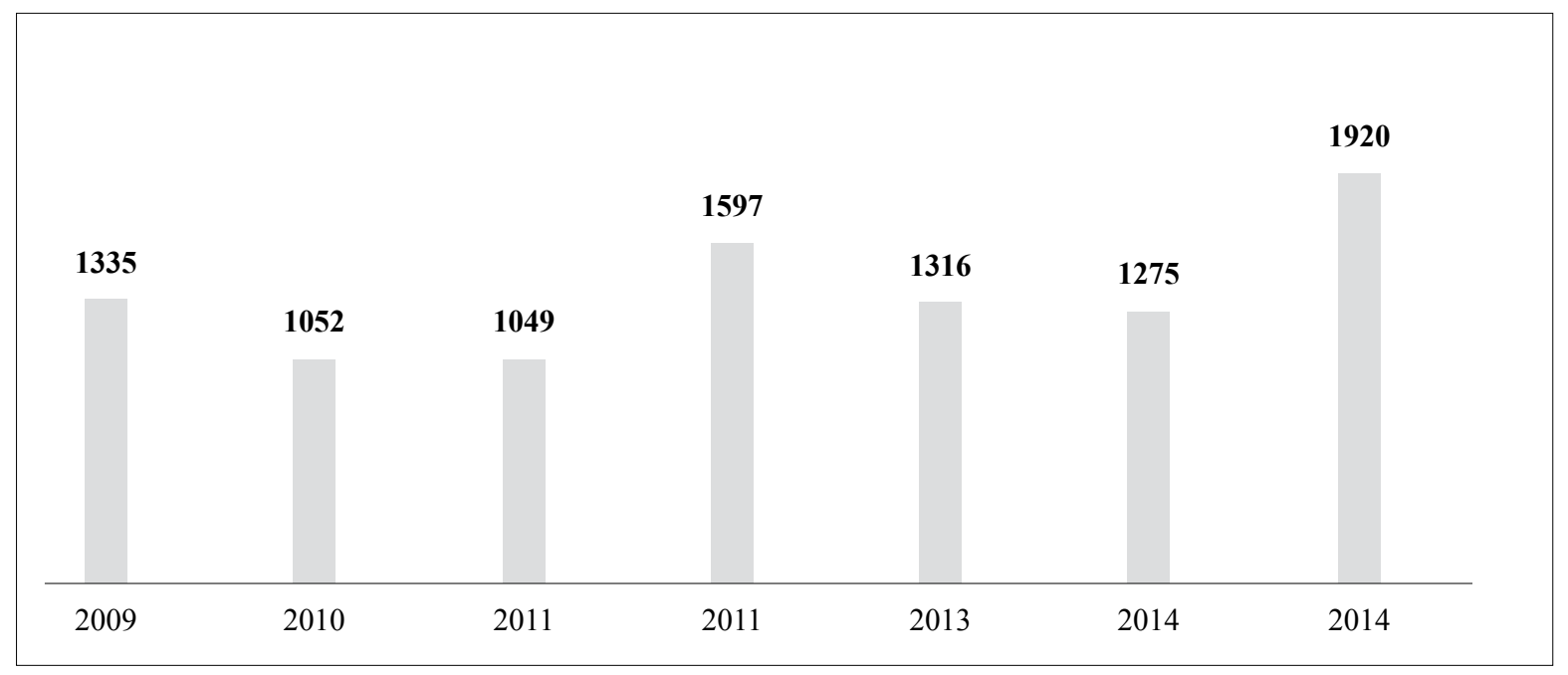

Fig. 11. Migrants arriving through the eastern borders 2009-2015 


\section{Conclusions}

As this paper proves, migration is as old as mankind, such as a part of the routes that they use to travel to Europe. It is also proved that these paths change every now and then - especially due to the challenges and different political- economic environment -, so intensive control or the total block of routes may result in only temporary effects. This can give an opportunity to the concerned states to elaborate on their appropriate and coordinated procedures in connection with illegal migration. It can be a huge challenge for the international community to handle an acute immigration crisis arising from border closure and the stricter border control, which may lead to the deterioration in bilateral relationships, however in the future it should also be an optional motivator or a casus belli for a possible armed conflict.

Now it seems that migratory waves can be controlled and restricted up to a certain level, but cannot be stopped. It is not easy to find an individual solution, and the neighbouring states' private counter-immigration policy may also risk the plan. This is why cooperation and active dialogue among both sending, affected (transit) and recipient countries are considered as a key element in the recent international stabilizing mechanisms.

\section{References}

Altai Consulting; IOM MENA Regional Office 2015. Migration Trends Across the Mediterranean: Connecting the Dots. Availble on the Internet: $<\mathrm{http} / / /$ www.altaiconsulting.com/docs/migration/Altai_Migration_trends_accross_the_Mediterranean.pdf $>$

Altai Consulting; UNHCR 2013. Mixed Migration: Libya at the Crossroads. Mapping of Migration Routes and Drivers of Migration in Post-revolution Libya, Tripoli. Availble on the Internet: $<$ http://www.altaiconsulting.com/mixedmigrationlibya/Altai_ConsultingUNHCR-Mixed_Migration_Libya.pdf>

Besenyő J. 2011. Nyugat-Szahara és a migráció [Western Sahara and migration]. Afrika Tanulmányok. 5: 35-45.

Bob-Milliar, G. M.; Bob-Milliar, G.K. 2013. The Politics of Trans-Saharan Transit Migration in the Maghreb: Ghanaian Migrants in Libya, c.1980 - 2012. African Review of Economics and Finance. 5(1): 60-73.

Borelli, S.; Stanford, B. 2014. Troubled Waters in the Mare Nostrum: Interception and Push-backs of Migrants in the Mediterranean and the European Convention on Human Rights. Uluslararası Hukuk ve Politika.. 10(37): 29-69.

Brian, T.; Laczko, F. 2014. Fatal Journeys, Tracking lives lost during migration. International Organisation for Migration, Geneva. Availble on the Internet: <https:/www.iom.int/files/live/sites/iom/files/pbn/docs/Fatal-Journeys-Tracking-Lives-Lost-during-Migration-2014.pdf>

Castan Pinos, J. 2009. Building Fortress Europe? Schengen and the Cases of Ceuta and Melilla, School of Politics, International Studies and Philosophy Queen's University Belfast, Belfast. Available ont he Internet: $<$ https://www.qub.ac.uk/research-centres/CentreforInternationalBordersResearch/Publications/WorkingPapers/CIBRWorkingPapers/Filetoupload,174398,en.pdf >

De Bruycker, P.; Di Bartolomeo, A.; Fargues, P. 2013. Migrants smuggled by sea to the EU: facts, laws and policy options, MIGRATION POLICY CENTRE. Availble on the Internet: <http://www.migrationpolicycentre.eu/docs/MPC-RR-2013-009.pdf $>$

De Haas, H. 2007. Irregular Migration from West Africa to the Maghreb and the European Union: An Overview of Recent Trends, International Organization for Migration, Geneva. Availble on the Internet: $<$ http://www.heindehaas.com/Publications/de $\% 20 \mathrm{Haas} \% 20$ 2008\%20MRS-32_EN.pdf>

Del Grande, G. 2016. Fortress Europe database. Availble on the Internet: <http://fortresseurope.blogspot.hu/p/la-strage.html>

Dimitriadi, A. 2016. Managing Europe's external borders, European Council on Foreign Relations. Availble on the Internet: <http:// www.ecfr.eu/article/commentary_managing_europes_external_borders>

Düvel, F.; Vollmer, B. 2011. European Security Challanges, European University Institute. Availble on the Internet: <http://cadmus.eui. eu/bitstream/handle/1814/16212/EU-US\%20Immigration\%20Systems2011_01.pdf?sequence=1\&isAllowed=y>

ECOWAS 2006. The Atlas on Regional Integration in West Africa. ECOWAS- SWAC/OECD. Availble on the Internet: <http://www. oecd.org/migration/38409521.pdf>

European Commission DG Migration and Home Affairs 2015. A study on smuggling of migrants, Characteristics, responses and cooperation with third countries. Availble on the Internet: <http://ec.europa.eu/dgs/home-affairs/what-we-do/networks/european_migra- 
tion_network/reports/docs/emn-studies/study_on_smuggling_of_migrants_final_report_master_091115_final_pdf.pdf>

European External Action Service 2015. Interim strategic review of EUBAM Libya. Availble on the Internet: <http://www.statewatch. org/news/2015/jun/eu-eeas-interim-report-UBAM-7886-15.pdf>

European External Action Service 2016. EUNAVFOR MED - Operation SOPHIA, Six Monthly Report: June, 22nd to December, 31st 2015. Availble on the Internet: <https://wikileaks.org/eu-military-refugees/EEAS/EEAS-2016-126.pdf >

Fargues, P.; Bonfanti, S. 2014. When the best option is a leaky boat: why migrants risk their lives crossing the Mediterranean and what Europe is doing about it, Migration Policy Centre, EUI. Availble on the Internet: < http://cadmus.eui.eu/bitstream/handle/1814/33271/ MPC_PB_2014-05.pdf?sequence=1>

Fasani, F. 2009. Undocumented Migration: Counting the Uncountable: Data and Trends across Europe. Availble from: <http://irregular-migration.net/typo3_upload/groups/31/4.Background_Information/4.4.Country_Reports/Italy_CountryReport_Clandestino_ Nov09_2.pdf>

Frontex 2010a. Extract from the Annual Risk Analysis 2010. Warsaw. Availble on the Internet: <http://frontex.europa.eu/assets/Publications/Risk_Analysis/Annual_Risk_Analysis_2010.pdf>

Frontex 2010b. Joint Operation Hera: 'The Birth of Sea Operations'. in Beyond the Frontiers: Frontex: the first five years, Warsaw. Availble on the Internet: <http://frontex.europa.eu/assets/Publications/General/Beyond_the_Frontiers.pdf $>$

Frontex 2011a. Annual Risk Analysis 2011. Warsaw. Availble on the Internet: < http://frontex.europa.eu/assets/Publications/Risk_Analysis/Annual_Risk_Analysis_2011.pdf>

Frontex 2011b. Western Balkans Annual Risk Analysis 2011. Warsaw. Availble on the Internet: <http://frontex.europa.eu/assets/Publications/Risk_Analysis/WB_ARA_2011.pdf>

Frontex 2012. Annual Risk Analysis 2012. Warsaw. Availble on the Internet: <http://frontex.europa.eu/assets/Publications/Risk_Analysis/Annual_Risk_Analysis_2012.pdf>

Frontex 2013. Annual Risk Analysis 2013. Warsaw. Avalible from: $<$ http://frontex.europa.eu/assets/Publications/Risk_Analysis/Annual_Risk_Analysis_2013.pdf>

Frontex 2014. Annual Risk Analysis 2014. Warsaw. Availble on the Internet: <http://frontex.europa.eu/assets/Publications/Risk_Analysis/Annual_Risk_Analysis_2014.pdf>

Frontex 2015a. Migratory routes map. Availble on the Internet: <http://frontex.europa.eu/trends-and-routes $>$

Frontex 2015b. Annual Risk Analysis 2015. Warsaw. Availble on the Internet: < http://frontex.europa.eu/assets/Publications/Risk_Analysis/Annual_Risk_Analysis_2015.pdf>

Frontex 2016a. Africa-Frontex Intelligence Community Joint Report. Warsaw. Availble on the Internet: <http://frontex.europa.eu/assets/ Publications/Risk_Analysis/AFIC/AFIC_report_2015.pdf $>$

Frontex 2016b. FRAN Quarterly: Quarter 4: October-December 2015. Warsaw. Availble on the Internet: <http://frontex.europa.eu/ assets/Publications/Risk_Analysis/FRAN_Q4_2015.pdf>

Frontex launches Joint Operation Triton, 31.10.2014. Frontex. Availble on the Internet: $<$ http://frontex.europa.eu/news/frontex-launches-joint-operation-triton-JSYpL7>

Global Initiative against Transnational Organized Crime 2014. Smuggled Futures: The dangerous path of the migrant from Africa to Europe, Research report. Geneva. Availble on the Internet: <http://www.globalinitiative.net/smuggled-futures/>

Human Rights Watch 2015. The Mediterranean Migration Crisis - Why People Flee, What the EU Should Do. Availble on the Internet: $<$ https://www.hrw.org/sites/default/files/reports/eu0615_web.pdf>

International Crisis Group 2015. The Central Sahel: A Perfect Sandstorm, Crisis Group Africa Report $N^{\circ} 227$. Brussels. Availble on the Internet: <http://www.crisisgroup.org/ /media/Files/africa/west-africa/227-the-central-sahel-a-perfect-sandstorm.pdf>

IOM 2015. Irregular Migrant, Refugee Arrivals in Europe Top One Million in 2015. Availble on the Internet: <https://www.iom.int/ news/irregular-migrant-refugee-arrivals-europe-top-one-million-2015-iom>

Kuschminder, K.; De Bresser, J.; Siegel, M. 2015. Irregular Migration Routes to Europe and Factors Influencing Migrants'Destination Choices. Availble on the Internet: <https://english.wodc.nl/images/2553-volledige-tekst-en_tcm45-596572.pdf> 
Llewellyn, S. 2015. Search and Rescue in Central Mediterranean Sea: Mission Echanges et Partenariats, Migreurop, Watch the Med, Arci, 02/02-08/06/2015. Availble on the Internet: <http://www.migreurop.org/IMG/pdf/report_wtm_migreurop-arci-ep_08242015.pdf>

Martín, I.; Bonfanti, S. 2015. Migration and Asylum Challenges in Eastern Africa: Mixed Migration Flows Require Dual Policy Approaches, Migration Policy Centre, EUI. Availble on the Internet: <http://cadmus.eui.eu/bitstream/handle/1814/35038/MPC_201504_PB.pdf?sequence $=1>$

Migreurop; Gadem 2015. Ceuta \& Melilla, centres de tri á ciel ouvert aux portes de l'Afrique. Availble on the Internet: $<$ http://www. migreurop.org/IMG/pdf/fr_rapportconjoint_ceutamelilla_decembre2015.pdf $>$

MIGREUROP 2010. European borders Controls, detention and deportations, 2009/2010 Report. Paris. Availble on the Internet: $<$ http:// www.epim.info/wp-content/uploads/2011/02/European-borders-controls-detention-deportations-Migreurop-Report-2010.pdf>

Ministero dell'Interno 2014. Presenze dei migranti nelle strutture di accoglienza in Italia. Availble on the Internet: $<\mathrm{http}: / / \mathrm{www} . i n t e r n o$. gov.it/sites/default/files/presenze_dei_migranti_nelle_strutture_di_accoglienza_in_italia.pdf>

Ministero dell'Interno 2015. Presenze dei migranti nelle strutture di accoglienza in Italia. Availble on the Internet: $<$ http://www.interno. gov.it/sites/default/files/dati_per_sito_da_marzo_a_dicembre_2015.pdf $>$

Missing Migrants Project. IOM. Availble on the Internet: $<$ http://missingmigrants.iom.int $>$

Monzini, P. 2003. Migrant smuggling via maritime routes, Centro Studi di Politica Internazionale. Availble on the Internet: http://www. cespi.it/cnr/Monzini-ing.pdf

Njaramba, J.; Chigeza, P.; Whitehouse, H. 2015. Financial literacy:the case of migrant African-Australian women entrepreneurs in the cairns region, Entrepreneurship and Sustainability Issues 3(2): 198-208.http://dx.doi.org/10.9770/jesi.2015.3.2(7)

Parkes, R. 2014. Integrating EU defence and migration policies in the Mediterranean, Working paper, no. 125, Fundación para las Relaciones Internacionales y el Diálogo Exterior. Availble on the Internet: <http://fride.org/download/WP_125_Integrating_EU_defence_and_migration_policies_in_the_Mediterranean.pdf>

Regional Mixed Migration Secretariat 2013. Migrant Smuggling in the Horn of Africa \& Yem the political economy and protection risks. Nairobi. Availble on the Internet: $<$ http://www.regionalmms.org/fileadmin/content/rmms_publications/Migrant_Smuggling_in the_Horn_of_Africa_and_Yemen._report.pdf $>$

Reitano, T.; Tinti, P. 2015. Survive and advance The economics of smuggling refugees and migrants into Europe, Institute for Security Studies, ISS paper 289. Availble on the Internet: <https://www.issafrica.org/uploads/Paper289-2.pdf $>$

Reitano, T. 2015. Perilous but Profitable Crossing: The Changing Nature of Migrant Smuggling through sub-Saharan Africa to Europe and EU Migration Policy (2012-2015). The European Review of Organised Crime. 2(1): 1-23.

Rezk, M. A.; Ibrahim, H. H.; Radwan, A.; Sakr, M. M.; Tvaronavičienè, M.; Piccinetti, L. 2016. Innovation magnitude of manufacturing industry in Egypt with particular focus on SMEs, Entrepreneurship and Sustainability Issues 3(4): 306-318. http://dx.doi.org/10.9770/ jesi.2016.3.4(1)

Rezk, M. A.; Ibrahim, H. H.; Tvaronavičiené, M.; Sakr, M. M.; Piccinetti, L. 2015. Measuring innovations in Egypt: case of industry, Entrepreneurship and Sustainability Issues 3(1): 47-55.http://dx.doi.org/10.9770/jesi.2015.3.1(4)

Schapendonk, J. 2012. Turbulent Trajectories: African Migrants on Their Way to to the European Union. Availble on the <Internet: www.mdpi.com/2075-4698/2/2/27/pdf>

Šimelytė, A.; Ševčenko, G.; El Amrani El Idrissi, N.; Monni, S. 2016. Promotion of renewable energy in Morocco, Entrepreneurship and Sustainability Issues 3(4): 319-328. http://dx.doi.org/10.9770/jesi.2016.3.4(2)

Shelley, L. 2014. Human Smuggling and trafficking into Europe - A comperative perspective, Migration Policy Institute. Availble on the Internet: <http://www.migrationpolicy.org/sites/default/files/publications/BadActors-ShelleyFINALWEB.pdf >

UNHCR 2016. Europe refugees \& migrants emergency response nationality of arrivals to Greece, Italy and Spain. Availble on the Internet: $<$ http://data.unhcr.org/mediterranean/regional.php $>$

UNITED Against Refugee Deaths 2015. List of 22.394 documented deaths of asylum seekers, refugees and migrants due to the restrictive policies of Fortress Europe. Availble on the Internet: <http://www.unitedagainstracism.org/wp-content/uploads/2015/06/Listofdeaths22394June15.pdf>

UNODC 2013. Smuggling of migrants from West Africa to Europe. Availble on the Internet: <https://www.unodc.org/documents/toc/ 


\section{Reports/TOCTAWestAfrica/West_Africa_TOC_MIGRANTS.pdf>}

UNODC Regional Office for West and Central Africa 2012. Regional Strategy for Combating Trafficking in Persons and Smuggling of Migrants 2015-2020. Availble on the Internet: <https://www.unodc.org/documents/westandcentralafrica/UNODC_Regional_Strategy_for_Combating_TIP_SOM_West_and_Central_Africa_2015-2020.pdf $>$

Urban, T. 2015. Distant Shores? Evaluating Spain's Immigration Policy. CEJISS. 9(2). Availble on the Internet: <http://www.cejiss.org/ issue-detail/distant-shores-evaluating-spain-s-immigration-policy>

van Reisen, M.; Estefanos, M.; Rijken, C. 2013. The Human Trafficking Cycle: Sinai and Beyond [Draft], Wolf Legal Publishers, Oisterwijk. Availble on the Internet: http://www.eepa.be/wcm/dmdocuments/Small_HumanTrafficking-Sinai2-web-3.pdf

János BESENYÖ, Phd is the Head of the Scientific Research Department of the Military Staff. His areas of research are Africa and the Middle-East as well as peace-keeping, military logistics, Hungarian peace keeping operations in Africa, especially in Western-Sahara, over and above the comparison of political cultures, political communication and intercultural communication, institution of kids army, DDR programs in Africa, terrorism, respectively the Christian - Muslim opposition on the continent. He served many times in Africa (Western-Sahara, Darfur) and Afghanistan. He completed his doctor degree in the science of military in 2011 on the Miklós Zrínyi National Defense University. He teaches as a teacher in the Military Science School of the National Public Service, University of Eötvös Lóránd and also at the Sándor Wekerle Business Collage. 